\title{
Review of Established and Emergent Methods for the Production of C4 Olefins
}

James Matthew Koval

West Virginia University, jmkoval@mix.wvu.edu

Follow this and additional works at: https://researchrepository.wvu.edu/etd

Part of the Biochemical and Biomolecular Engineering Commons, Catalysis and Reaction Engineering Commons, and the Other Chemical Engineering Commons

\section{Recommended Citation}

Koval, James Matthew, "Review of Established and Emergent Methods for the Production of C4 Olefins" (2020). Graduate Theses, Dissertations, and Problem Reports. 7768.

https://researchrepository.wvu.edu/etd/7768

This Problem/Project Report is protected by copyright and/or related rights. It has been brought to you by the The Research Repository @WVU with permission from the rights-holder(s). You are free to use this Problem/Project Report in any way that is permitted by the copyright and related rights legislation that applies to your use. For other uses you must obtain permission from the rights-holder(s) directly, unless additional rights are indicated by a Creative Commons license in the record and/ or on the work itself. This Problem/Project Report has been accepted for inclusion in WVU Graduate Theses, Dissertations, and Problem Reports collection by an authorized administrator of The Research Repository @ WVU. For more information, please contact researchrepository@mail.wvu.edu. 


\title{
Review of Established and Emergent Methods for the Production of $\mathrm{C}_{4}$ Olefins
}

\author{
James M. Koval \\ Problem Report submitted to the Statler College of Engineering and Mineral Resources \\ at West Virginia University \\ in partial fulfillment of the requirements for the degree of \\ Master of Science in Chemical Engineering \\ Jianli Hu, Ph.D., Chair \\ Charter D. Stinespring, Ph.D. \\ Jeremy S. Hardinger, Ph.D.
}

Department of Chemical and Biomedical Engineering

\author{
Morgantown, West Virginia
}

Summer 2020

Keywords: $\mathrm{C}_{4}$, olefin, alkene, synthesis, biocatalysis, butadiene, butene Copyright 2020 James Koval 


\begin{abstract}
Review of Established and Emergent Methods for the Production of $\mathrm{C}_{4}$ Olefins
\end{abstract}

James Koval

Current production of $\mathrm{C}_{4}$ olefins is dominated by naphtha cracking and butane dehydrogenation, but significant research interest is developing in alternate feedstocks due to an abundance of inexpensive natural gas and bioethanol. The current $\mathrm{C}_{4}$ olefin production methods are costly, make use of already-depleted petroleum resources, and are often hazardous to workers, which forms the impetus for investigation into alternative methods and assessment of their viability as a future means of olefin production. Methods of natural gas conversion to higher order hydrocarbons are discussed, including Fischer-Tropsch synthesis and oxidative methane coupling, each of which could form the first step in a hypothetical natural gas-to-olefins process. The historically common Lebedev, Ostromislensky, and Fripiat methods for 1,3-butadiene production from ethanol feedstocks are described and analyzed, although these processes largely fell out of favor in the decades following World War II in favor of sources derived from naphtha cracking. Another well-known process involving $\mathrm{C}_{4}$ olefins, olefin metathesis, is considered, although the reaction is more commonly used to produce propylene. Biological processes are discussed as well, including the well-known production of bioethanol from sugars and starches, and also more novel processes such as an effort to use genetically engineered microorganisms to produce specific intermediates for olefin production, and in some cases, direct olefin production from these organisms. Finally, several promising schemes are identified and analyzed, in an attempt to compare their potential viability in key areas. Two of the most promising emergent methods today identified in this review are the bio-catalyzed production of 1,4-butanediol and/or butadiene using $E$. coli, and a microwave radiation-assisted scheme in which methane is selectively dimerized twice to form 1-butene. 


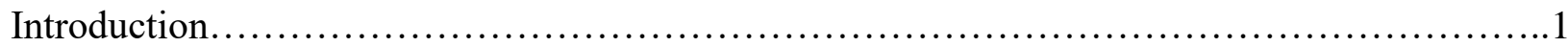

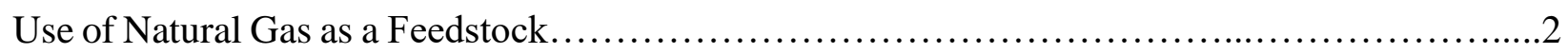

Fischer-Tropsch Synthesis for Carbon Chain Elongation...........................

Oxidative Methane Coupling to $\mathrm{C}_{2}$ Alkanes and Alcohols.........................

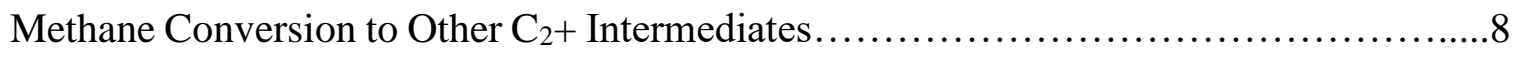

Biological Methods of Obtaining Feedstocks for the Synthesis of $\mathrm{C}_{4}$ Olefins....................

Butanediol Conversion to Butadiene.........................................

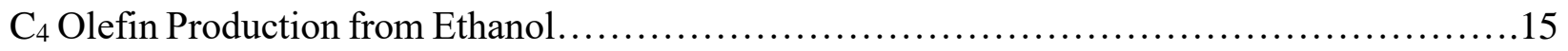

Lebedev Process and Other One-Step Methods................................ 16

Ostromislensky Process and Other Two-Step Methods..............................19

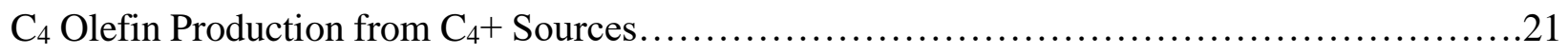

Olefin Metathesis..............................................................22

Cost/Benefit Discussion for Selected Reaction Schemes..................................24

Mixed Butenes Distillation Scheme Analysis..................................27

Ethanol-to-Butadiene Scheme Analysis......................................29

Olefin Metathesis Scheme Analysis....................................... 31

Biocatalysis Scheme Analysis............................................. 32

Microwave-Assisted Methane Conversion Scheme Analysis........................33

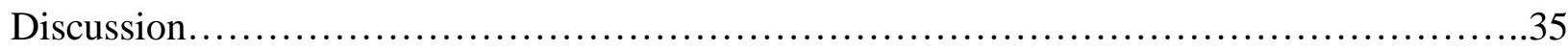

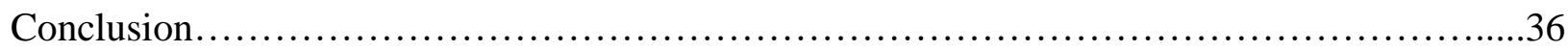

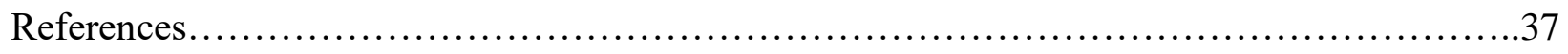




\section{Introduction}

Olefins, or alkenes, are a highly important industrial chemical class consisting of an unsaturated hydrocarbon chain containing one or more double $\mathrm{C}=\mathrm{C}$ bonds. Common olefins, such as ethylene and propylene, are precursors to polyethylene and polypropylene respectively, two highly important polymers used in a wide variety of commercial plastics. Although ethylene and propylene are among the two most massively produced olefins, and thus have attracted an abundance of research into different effective methods of synthesis, higher-order olefins $\left(\mathrm{C}_{4}\right.$ and above) have not been directly synthesized as readily. Instead, $\mathrm{C}_{4}+$ olefins have historically been produced via the selective dehydrogenation of $\mathrm{C}_{4}+$ alkanes or as a byproduct from other processes such as naphtha cracking. An estimated 95 percent of worldwide production of 1,3butadiene, an important polyunsaturated olefin used in the production of rubber for automobile tires, was produced in one (or both) of these two ways as of 2018 [15]. These processes, which already rely on the use of $\mathrm{C}_{4}+$ feedstocks, leave the price of the important $\mathrm{C}_{4}$ olefins in flux due to inconsistent feedstock supply, and may be unsustainable regardless due to limited natural resources, creating the impetus for a well-established direct synthesis route to these important monomers $[1,3,12-15]$.

Direct synthesis of $\mathrm{C}_{4}$ olefins such as $1,3-\mathrm{BD}$ is not without precedent, however. During World War II, a natural rubber shortage necessitated an investigation into synthetic routes of 1,3butadiene monomer creation for use in rubber production for military vehicles. Around this time, two different processes were developed, both using ethanol as a feed source for butadiene synthesis: the one-step Lebedev process and the two-step Ostromislensky process $[12,16]$. Although these ethanol-as-feedstock routes were once popular for on-purpose 1,3-butadiene synthesis, particularly the Lebedev process, they were largely abandoned industrially in Europe 
and the US by the 1960s in favor of butane/butene dehydrogenation schemes [3]. By 1990, only one stand-alone butadiene plant was operating in the United States [14]. To this day, the vast majority of 1,3-butadiene production takes place as a side unit in massive, preexisting ethylene plants. There, a mixed $\mathrm{C}_{4}$ byproduct stream diverted from the main ethylene production unit is fractionally distilled into its main components [12]. This separation between these isomers and other chemically similar compounds can be rather costly, and much of the raffinate left over after removal of butadiene and isobutene has no established commercial significance. There is renewed interest in an efficient and less expensive pathway for butadiene synthesis from $\mathrm{C}_{1}$ and $\mathrm{C}_{2}$ sources, partially due to an abundance of inexpensive and more environmentally friendly potential feedstocks such as natural gas and bioethanol attracting attention. A review of these emergent techniques, and a comparison and contrast of their potential for the future in $\mathrm{C}_{4}$ olefin production are proposed.

\section{Use of Natural Gas as a Feedstock}

In the years following the American shale gas boom of the early 2000s, much research attention has been focused towards getting value-added products out of a suddenly abundant and cheap supply of natural gas. Natural gas is mostly composed of methane and other low-order hydrocarbons, which can present a challenge when converting to heavier products. Methane, which comprises the vast majority of natural gas reserves, is particularly stable due to its tetragon structure consisting of four $\mathrm{C}-\mathrm{H}$, requiring a high temperature to break and form new bonds.

There is an inherent concern of allowing too much combustion to occur when operating at high temperatures. Thus, at the heart of the improvement of natural gas is the concern for lowering the activation energy required to break these $\mathrm{C}-\mathrm{H}$ bonds, via catalysis and other methods [11]. However, it is also important that the catalyst be able to discriminate between the strong $\mathrm{C}-\mathrm{H}$ 
bonds in methane and the relatively weak $\mathrm{C}-\mathrm{H}$ bonds in higher order hydrocarbons [5]. Therein lies a key problem in synthesizing higher order olefins from natural gas rather than using conventional methods such as cracking: adding carbons to a growing chain becomes increasingly difficult with each elongation. However, many potential pathways for these valuable conversions have been demonstrated in the literature, even if they have not yet been commercialized to a great extent. This report seeks to catalog, describe, analyze, and evaluate the efficacy of these methods.

There are three main categories of pathways demonstrated thus far for the activation of methane to form higher order products: syngas production, oxidative methane coupling, and direct conversion to said value-added chemicals [5]. Syngas, a mixture primarily consisting of hydrogen and carbon monoxide, has long been a highly researched topic as an intermediate for natural gas conversion and can be derived from a variety of cheap and environmentally friendly sources including natural gas, biomass, and industrial waste. Fischer-Tropsch synthesis and similar methods have been well documented to convert syngas to liquid hydrocarbons, and depending on process conditions and catalysis, can be used to generate $\mathrm{C}_{4}$ alkanes, alkenes, and alcohols from syngas. Oxidative methane coupling (OCM) is also of interest due to its ability to produce ethanol. Like syngas, ethanol is a highly researched molecule that is readily available from a variety of sources, and thus much is known about its potential for use to synthesize higher order chemicals. Finally, some methods for conversion of natural gas to higher order oxygenates have been discovered, although highly specialized catalysts are needed to achieve a viable selectivity and yield for the desired products.

There in an inherent challenge due to the disorder involved in combining relatively simple and stable $\mathrm{C}_{1}$ reactants to form more complex $\mathrm{C}_{4}$ products. Therefore, the control and 
suppression of undesired side products is a key goal for any and all synthesis processes. This also means that there is unlikely to be any simple, elegant solution, and that any worthwhile strategy for producing high yields of a single $\mathrm{C}_{4}$ olefin product will almost certainly employ a combination of the methods discussed herein. Although byproducts from intermediate reactions are likely to be unavoidable and may require additional equipment purchases, this may turn out to be a strength for a $\mathrm{C}_{4}$ olefin production operation, as prices can vary widely over the course of several years [12]. The ability to process byproducts could lend to the flexibility of a hypothetical stand-alone butadiene plant in the event that there is a price drop for a previously desired product or value increase for a chemical not currently being produced in large quantities.

In summary, the methane conversion methods offer some promise as they are versatile and have abundant feed sources, but the reactions are usually difficult to control, and typical yields in most contemporary research are too low to attract more widespread attention from companies and investors. A review of literature has been conducted to evaluate the efficacy and viability of these methods for natural gas improvement, detailed in the following sub-sections.

\section{Fischer-Tropsch Synthesis for Carbon Chain Elongation}

One of the most common methods for conversion of methane and natural gas involves the production of synthesis gas (“syngas”), a moderately-energy dense mixture of hydrogen, carbon monoxide, and often carbon dioxide. Looking at natural gas as well as syngas from biomass and coal, Liu et al. formed mixed $\mathrm{C}_{2}+$ alcohols using modified Fischer-Tropsch synthesis [8]. These reactions were primarily catalyzed with copper-doped cerium oxide and zinc oxide-based catalysts. Results were mixed, with the resulting catalyst mostly producing methanol from syngas and showing just under 40 percent selectivity for $\mathrm{C}_{2}+$ alcohols. Somewhat unexpectedly, however, a large majority of the non-methanol product was found to be isobutanol, possibly due 
to the low heat of enthalpy/Gibbs energy of isobutanol. This phenomenon occurred for both metals, and was particularly pronounced in the ceria catalyst [8].

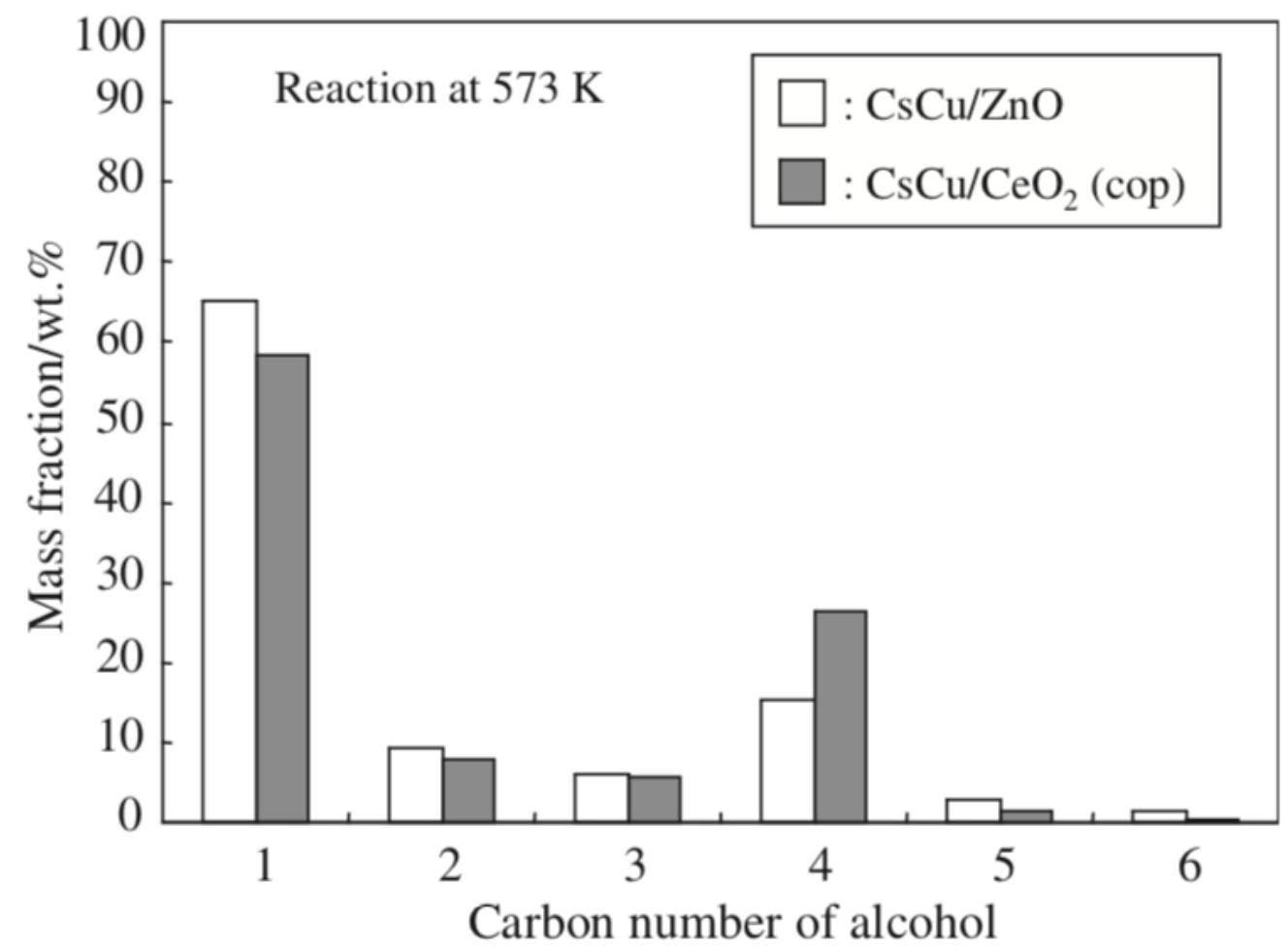

Figure 1: Proportions of carbon numbers of alcohols formed via the cesium-copper-doped catalysts, showing high relative abundance of $\mathrm{C}_{1}$ alcohols followed curiously by $\mathrm{C}_{4}$ (mostly isobutanol). The increased $\mathrm{C}_{4}$ selectivity was especially prevalent in the ceria coprecipitated catalyst. From Liu et al. [8]

This effect of increased stability in $\mathrm{C}_{4}$ isobutanol as opposed to lower-order alcohols could be worth consideration towards the goal of production of $\mathrm{C}_{4}$ olefins. However, selectivity of isobutanol relative to methanol was poor, and with isobutanol being a branched molecule, C-C bonds would still need to break and reform to form straight-chain $\mathrm{C}_{4}$ olefins such as 1,3 butadiene. Buniazet et al. demonstrated the potential of titanium/silicon oxide media to catalyze the dehydration of isobutanol. Although conversion was relatively low at 38 percent, more literature on this under-researched topic would be useful to determining whether this particular 
modified Fischer-Tropsch method using ceria as a catalyst and isobutanol as a key intermediate could ever be viable industrially.

Other metal oxides have been studied and show potential for modified Fischer-Tropsch synthesis of higher-order alcohols. Surisetty et al. examined the catalytic potential for molybdenum/potassium oxides and also sulfides supported on multi-walled carbon nanotubes. Both $\mathrm{CO}$ hydrogenation rate and Fischer-Tropsch synthesis rate increased when these nanotubes were employed as catalyst support over traditional formation methods such as coprecipitation and impregnation, most likely due to improved dispersion of the metallic active sites [10]. The use of carbon nanotubes for catalyst support in more studies, and for additional metals which showed a predilection to catalyst $\mathrm{C}_{4}$ alcohols would be a logical next step, such as cerium [8].

Another class of materials that have attracted interest as catalysts is metal carbides. Xiang et al. looked at molybdenum carbide catalysts with a variety of dopants and promoters. This particular catalyst showed high selectivity to methane, followed ethane and other alkanes; however, when potassium was added to the catalyst, selectivity of alcohols was "remarkably" increased, with ethanol becoming the most abundant product at a selectivity of around 40 percent [9]. Among many of the metal oxides and carbides, a small amount of nickel was found to increase selectivity for higher-order alcohols. Cobalt was also used in some instances as an effective promoter for this modified form of Fischer-Tropsch synthesis [8,10]. An addition of just 6 wt. percent cobalt to a Mo-K catalyst mounted on carbon nanotubes was found to increase $\mathrm{CO}$ conversion by half to 43.5 percent and more than doubled $\mathrm{C}_{3}+$ alcohol selectivity to 23 percent. Future research should incorporate these effective Fischer-Tropsch promoting metals into the more effective bulk catalysts for the hydrogenation of CO. At any rate, these modified F-T methods would likely require a major breakthrough in the form of increased selectivity of 
higher order products in order to be viable in comparison to more recent olefin production schemes discussed later in this review.

\section{Oxidative Methane Coupling to $\mathrm{C}_{2}$ Alkanes and Alcohols}

Another common route of carbon chain elongation using methane as a feedstock is oxidative methane coupling (OCM), either using oxygen gas or carbon dioxide as the oxidant. This reaction is difficult to control due to the potential of overoxidation of the methane feed to $\mathrm{CO}$ or to $\mathrm{CO}_{2}$ when oxygen is used as the sole oxidant. Cai and $\mathrm{Hu}$ demonstrated the use of $\mathrm{CO}_{2}$ as a co-fed oxidant to limit the production of undesired products and thus produce more hydrocarbons [5]. In this $\mathrm{CO}_{2}-\mathrm{OCM}$ process, an oxygen atom assists a $\mathrm{C}-\mathrm{H}$ bond break in methane, creating methyl radicals which combine to form ethane or ethylene. Many different mono- and multi-component catalysts were tested, including rare earth metals and oxides of calcium, zinc, lanthanum, manganese, and other elements. The $\mathrm{CO}_{2}-\mathrm{OCM}$ method had mixed results in this case, achieving high hydrocarbon selectivity above 80 percent, but with low yields no greater than 11 percent [5]. More conventional OCM methods using oxygen as the co-fed oxidant for methane $\left(\mathrm{O}_{2}-\mathrm{OCM}\right)$ were found to have similarly high selectivity around 80 percent for $\mathrm{C}_{2}$ hydrocarbons, and significantly higher yields of 25-30 percent. Undesired formation of combustion products such as $\mathrm{CO}$ and $\mathrm{CO}_{2}$ are limited by performing $\mathrm{O}_{2}-\mathrm{OCM}$ under conditions in which oxygen in clearly the limiting reactant [6].

In general, there are multiple reasons that oxidative methane coupling is considered difficult to effectively commercialize. Although selectivity of $\mathrm{C}_{2}$ hydrocarbons is often high, yields are often below 10 percent due to the care taken to avoid over-oxidation at high temperatures to products of combustion [6]. The desired reaction is also thermodynamically difficult, due to the relative strength of the $\mathrm{C}-\mathrm{H}$ bonds in methane compared to the slightly 
weaker C-H bonds in ethane [5]. Some researchers noted that little economic data existed for the process existed in the literature. However, the method has some favorable qualities such as the avoidance of the production or use of syngas, which is often a costly process only viable at massive scales [6]. A key concern for any future research interest in $\mathrm{CO}_{2}-\mathrm{OCM}$ would need to focus on effectively catalyzing the scission of the methane bonds without affecting the bonds in the desired $\mathrm{C}_{2}+$ products.

\section{Methane Conversion to Other $\mathbf{C}_{2}+$ Intermediates}

Although the main established methods for carbon chain elongation are the previously mentioned Fischer-Tropsch synthesis and OCM strategies, other studies have looked to establish a more direct link between lower-order hydrocarbon gases and higher order products than previous studies. One of these studies, conducted by Julian et al., used molybdenum-containing zeolite catalysts to convert methane. Instead of conventional heating, microwave plasma technology was employed to provide the necessary heats of fusion without combusting the methane and essentially wasting feed. Acetylene was noted as a primary product, with a significant amount of both ethylene and benzene forming as well [32]. While each valuable products in their own right, they each contain strong bonds that inhibit further selective conversion to olefins. Other researchers have employed microwave-assisted methane conversion with promising results. Lu et al. attempted to selectively synthesize butene from methane using a very similar experimental set-up, with some key improvements [1]. Hydrogen gas was co-fed with high-selectivity methane to prevent excessive dehydrogenation to triple-bonded acetylene, and nickel-molybdenum oxide mounted on a silica support served as the catalyst for the twostage reactor. In the first stage, methane was coupled to form ethylene, with a maximum of 73.2 
percent methane conversion observed. In the second stage, ethylene was in turn coupled to form 1-butene with 89.4 percent selectivity [1].

The microwave heating study appears promising for the synthesis of the important industrial monomer 1,3-butadiene, pending a successful dehydrogenation taking place on the $3^{\text {rd }}$ carbon atom in the chain. In addition, the setup appears to be simple and employed a novel approach that has potential to be viable for the production of $\mathrm{C}_{4}$ olefins, 1-butene and 1,3butadiene, even on a relatively small scale. Unfortunately, Lu's study appears to be an anomaly and few, if any, further experiments to synthesize $\mathrm{C}_{4}$ olefins directly from natural gas have been attempted. More information on how the microwave heating may assist carbon chain elongation could help legitimize a commercial approach, necessitating further study for this now-promising field.

\section{Biological Methods of Obtaining Feedstocks for the Synthesis of $\mathrm{C}_{4}$ Olefins}

In addition to methane, other feedstocks have been considered by researchers for their potential in synthesizing $\mathrm{C}_{4}$ olefins, particularly those which can be obtained in a sustainable fashion. Ethanol is of some interest due to the many potential sustainable sources of ethanol production, including corn or sugar crops, i.e. primary sources [3]. Secondary sources of bioethanol include cellulosic waste and algae, and could be particularly interesting as part of a sustainable $\mathrm{C}_{4}$ olefin production operation. These secondary sources are beneficial as they do not divert as many natural resources or food crops that could otherwise be used to benefit society, and instead generate useful bioethanol from waste or otherwise inert material. Bioethanol can then, in turn, be converted to $\mathrm{C}_{4}$ olefins like butadiene via the well-established Lebedev process and other similar syntheses, which will be covered in greater detail later. 
Some start-up companies have begun to investigate new approaches for the synthesis of highly valuable chemicals such as $\mathrm{C}_{4}$ olefins. Genomatica, a bioengineering company, selectively manufactures microorganisms which convert low-order organic feedstocks to specific value-added chemicals. Recently, a genetically-engineered strain of Escherichia coli was developed by Genomatica for the selective conversion of sugars to 1,4-butanediol in a test plant scenario, with the concept being proven to be effective on at least a 2000-ton scale [3]. This unique method of selective chemical production is achieved by evaluating many strains of genetically-modified microorganisms, then performing extensive fermentation experiments with only the best performing microorganism strains; in this case using E. coli to feed on and convert food sugars to 1,4-butanediol [7].

With so many successive reactions necessary to convert the sugar molecule to the butanediol product, many enzymes were needed for bio-catalysis, some existing endogenously or naturally in the bacteria and some needing to be added to the $E$. coli DNA through genetic modification and foreign species. Initially, naturally occurring enzymes in the bacteria were used to metabolize food sugars and amino acids such as alpha-ketoglutarate to the important biological molecule succinate, using the TCA cycle native to most organisms. Then, along the proprietary reaction pathway, the important biological molecule CoA plays a key role in converting the four-carbon succinate molecule to an olefin. CoA attaches to one of the carboxylic acid ends of the chain, and is protonated by a passing NADPH molecule to leave behind an aldehyde in its place. Next, the aldehyde end of the chain is protonated again to form a hydroxyl or alcoholic group. This process is repeated once more, eventually forming the established butadiene precursor, 1,4-butanediol, with alcohol groups on either end of the four carbon chain [30]. This pathway is presented in Figure 2 in full detail. 


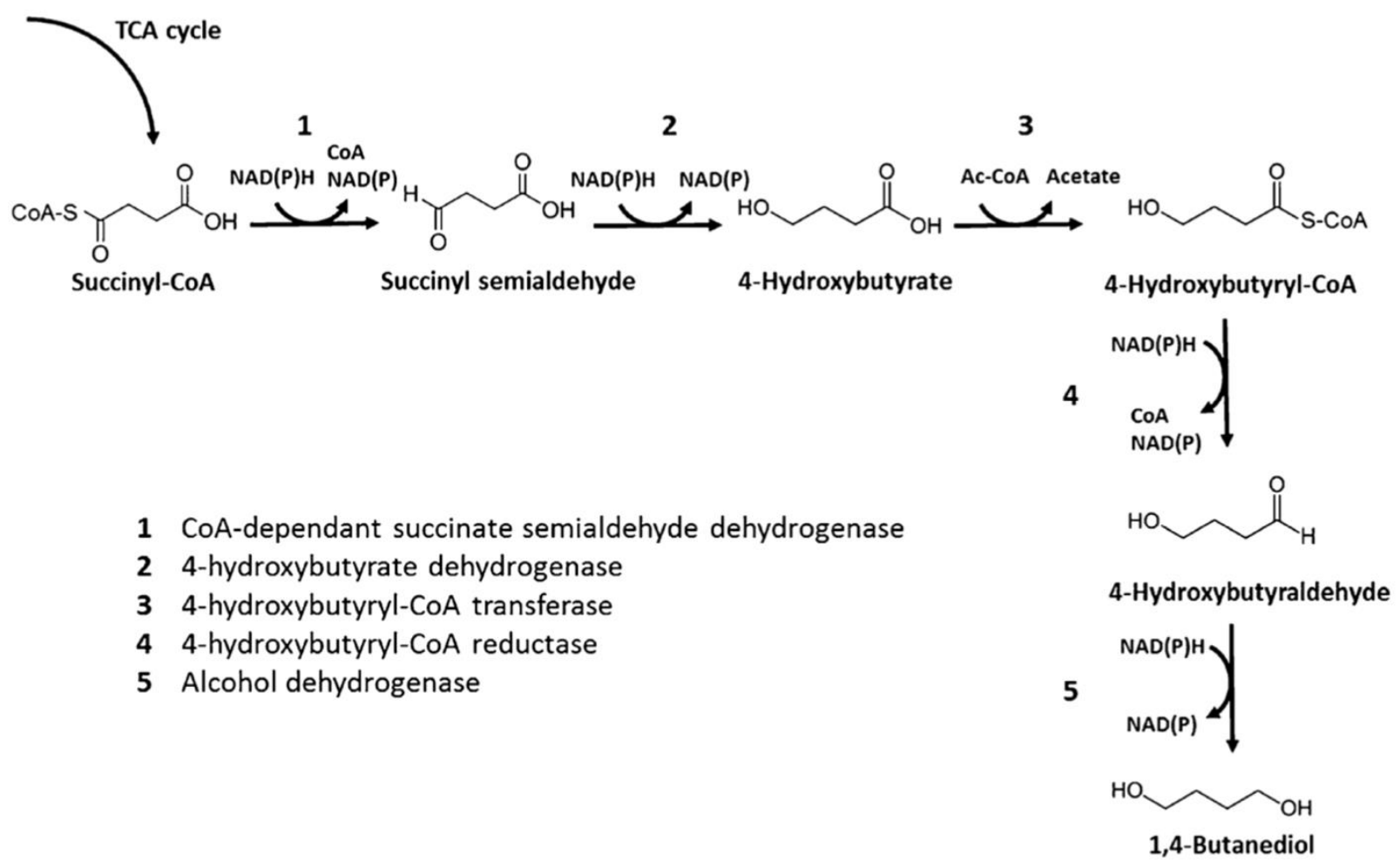

Figure 2: Main reaction network for the bio-based production of 1,4-butanediol in E. coli. Common metabolites such as succinate and alpha-ketoglutarate derived from the native TCA cycle are employed as the main reactants, and 4-hydroxybutarate forms a key intermediate. From Barton et al [7].

Although the technology is not yet at a globally viable stage, Genomatica has licensed the renewable 1,4-butanediol bioproduction process to larger companies for potential scale-up, and two commercial-scale plants: one with Novamont being a partner and another in conjunction with BASF, were scheduled in 2015 and 2017, respectively [3,27]. According to press releases from Genomatica, both plants have met early production goals and thus show great promise for the future of bio-butadiene production. Additionally, Genomatica has patented genetically modified E. coli to produce butadiene directly, using important biological molecules such as acetyl CoA and malonyl CoA in a fashion similar to their original 1,4-BDO production scheme [29]. A reaction schematic for this direct BD production route can be found in Figure 3 below. 


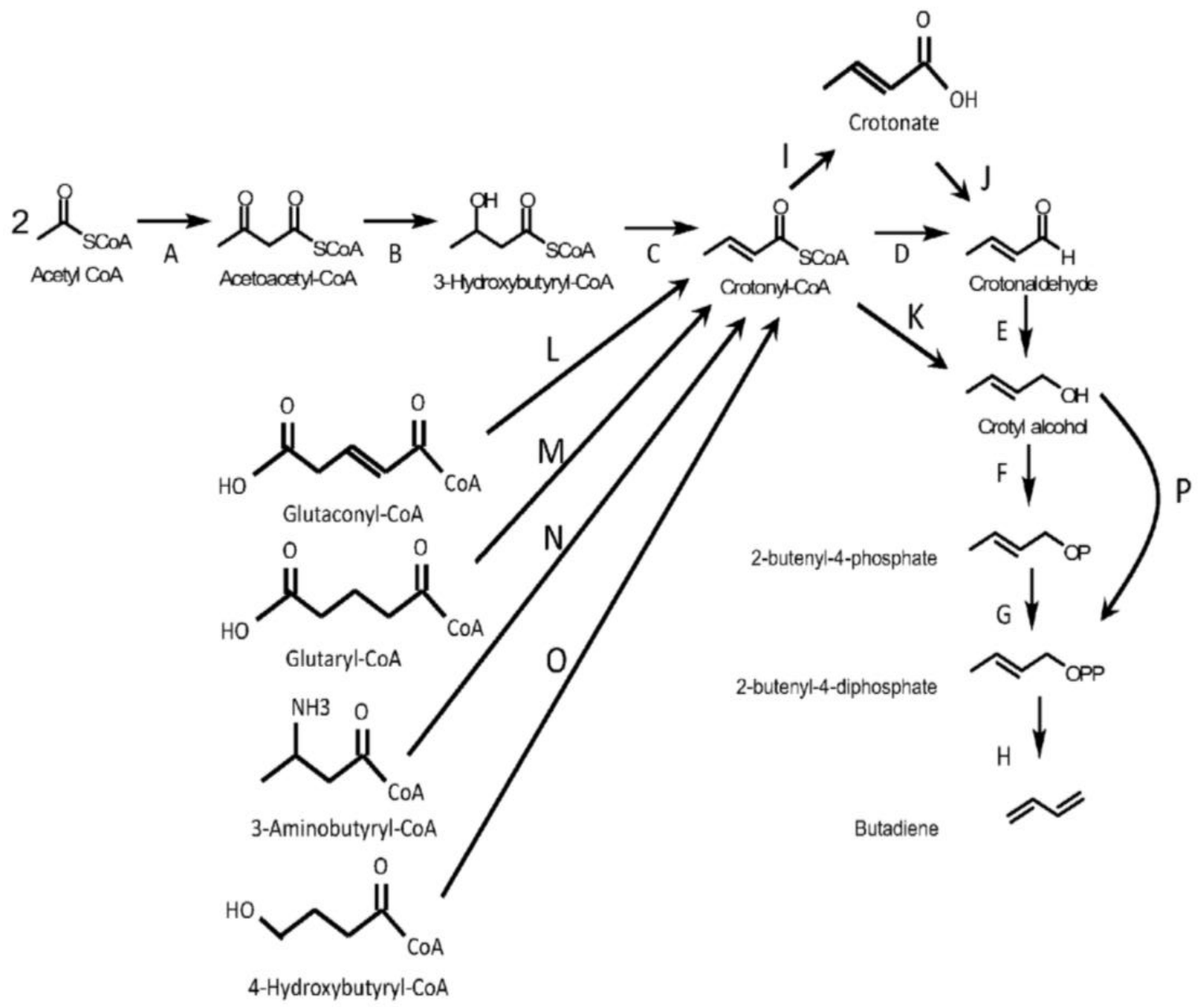

Figure 3: Genomatica's scheme for direct production of butadiene from various coenzymes in E. coli. AcetylCoA was primary reactant, but other molecules were used, with crotonaldehyde and croton alcohol forming key intermediates. From Burk et al [29].

As with the butanediol production scheme, a few of the necessary reactions early in the butadiene process could be catalyzed endogenously in the naturally-occuring E. coli organism. However, several genetic modifications were necessary in order to get the bacteria to diverge from its typical chemical pathway and produce butadiene gas [29]. Overall, the scheme is similar to that which is used for 1,4-butanediol production, with the main difference being a high-energy diphosphate ion added to the crotylalcohol (one internal double bond, one alcoholic group on the opposite end) in order to perform the final dehydration step to 1,3-butadiene. Research and commercial implementation of these exciting new processes is ongoing by 
companies large and small. In late 2016, the Italian chemical company Novamont, the first licensee of this technology from Genomatica, opened the world's first industrial bio-butanediol plant. By mid-2017, the company reported that production goals were being met and that over 10,000 tonnes of bio-based 1,4-butanediol had been produced for use as a chemical intermediate [50]. Renewable, bio-based feedstocks should be instrumental in modernizing the butadiene production industry, representing a vast improvement over petroleum-based routes for $\mathrm{BD}$ which are energy-intensive, inefficient, and hazardous to human health.

\section{Butanediol Conversion to Butadiene}

Although the use of bacteria to convert simple sugars to butanediol represents a great opportunity for $\mathrm{C}_{4}$ olefin production, 1,4-butanediol in and of itself is not a particularly useful product. With two successive dehydrations, 1,4-butanediol could potentially be converted to 1,3butadiene, thus completing the production of highly valuable and sought after $\mathrm{C}_{4}$ olefins from sugar with relatively little energy input. This potential reaction mechanism was proposed by Qi et al with 3-butene-1-ol as the key intermediate [15]. However, the use of conventional catalysts, both acidic and basic, can lead to problems, particularly the formation of cyclic compounds during dehydration rather than the straight chain butadiene [27,28]. Sato et al. used multiple metal oxides, including alumina, zirconia, silica, and ceria at varying temperatures and monitored product composition [28]. In order to maintain high butadiene selectivity, temperatures needed to remain below $300{ }^{\circ} \mathrm{C}$, which resulted in very low conversion of the $1,4-$ butanediol feed. At temperatures exceeding $400{ }^{\circ} \mathrm{C}$, conversion becomes much higher but the undesirable byproduct tetrahydrofuran dominates production. Of all the catalysts tested by Sato's team, ceria performed the best with an excellent BD selectivity over $85 \%$, but with a particularly low conversion rate of $6.3 \%$ at $275{ }^{\circ} \mathrm{C}$ [28]. 
With the rising interest in selective biofermentation for the formation of butadiene and the relative ineffectiveness of traditional metal oxide catalysts on 1,4-butanediol, many researchers began looking at other ways to catalyze this important dehydration to butadiene.

Ionic liquids have emerged a potential solution, particularly those involving the tetrabutylphosphonium (TBP) ion. Stalpaert, Cirujano, and de Vos examined the effectiveness of several TBP-halogenides as dehydration catalysts for diol conversion to desired dienes [27]. The study found that the compound $\mathrm{TBPBr}$ was extremely successful in forming both $\mathrm{C}_{4}$ and $\mathrm{C}_{6}$ dienes, and that none of the other halogenides tested (chloride or iodide) were nearly as effectively in catalyzing the successive dehydrations as bromide. A proposed reaction mechanism is included below in Figure 4. Using gas chromatography, the researchers were able to detect each of the proposed intermediates in limited quantities from the reaction effluent, supporting the validity of the proposed reaction network.

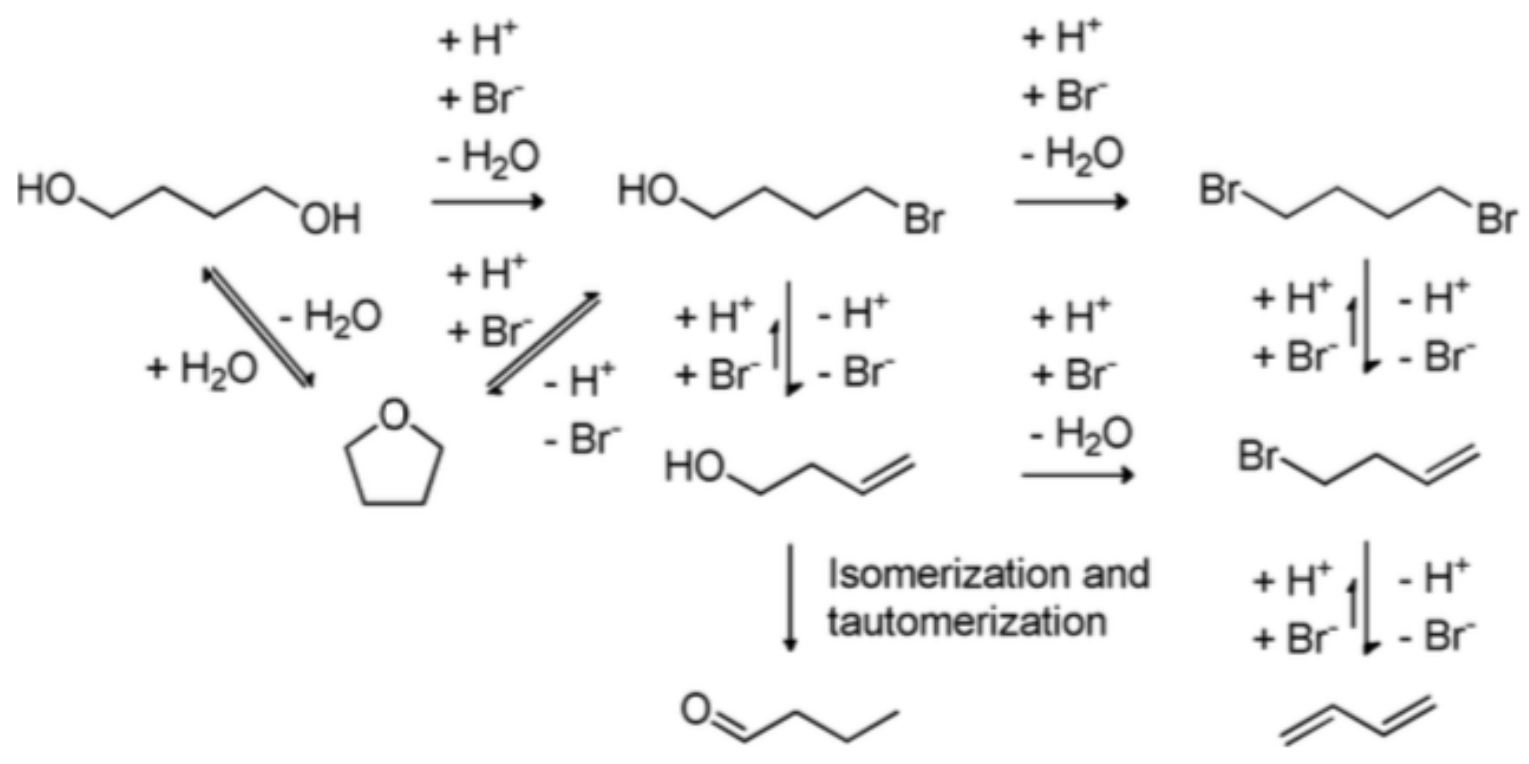

Figure 4: Proposed reaction network for the double dehydration of 1,4-butanediol to form 1,3-butadiene using TBPBr. In this case, the dehydration is aided by the bromide ion acting as a base, which is left behind in place of the alcohol group. The two dehydrations as well as the two dehydrobrominations to reach the final product can occur in any order. From Stalpaert, Cirujano, and de Vos [27]. 
The experimental setup which produced the best results involved the use of TBP-bromide as the catalyst at $220^{\circ} \mathrm{C}$, with some THF added to suppress the formation of THF as an intermediate, and some $\mathrm{HBr}$ added to provide acidic active sites for the dehydrations to occur. After 120 minutes reacting under these highly idealized conditions, an extremely high yield of 94\% 1,3-butadiene was reached [27]. In combination with promising bio-fermentation methods patented by companies like Genomatica, a fully "green" reaction mechanism for butadiene production from sugars or even waste such as cellulose could be a commercial possibility in the coming years.

\section{$\mathrm{C}_{4}$ Olefin Production from Ethanol}

In several of the aforementioned methods, particularly bioethanol production, the desired product is merely an intermediate for $\mathrm{C}_{4}$ olefin production. During World War II, a rubber shortage was the impetus for the development of at least two different methods of 1,3-butadiene production from ethanol: one-step Lebedev synthesis and two-step Ostromislensky synthesis. This 1,3-BD monomer was in turn used to synthesize polybutadiene and styrene-butadiene copolymers which are used as synthetic rubbers for automobile tires and the machines of war. Figure 5 contains a generalized reaction network for the coupling and conversion of ethanol to form 1,3-butadiene, showing that in addition to the coupling reaction, other reactions must occur to form the characteristic double bonds in 1,3-BD. Of course, many undesired side reactions and byproducts are possible and, in a sense, unavoidable due to the nature of a relatively complex one-step synthesis. 


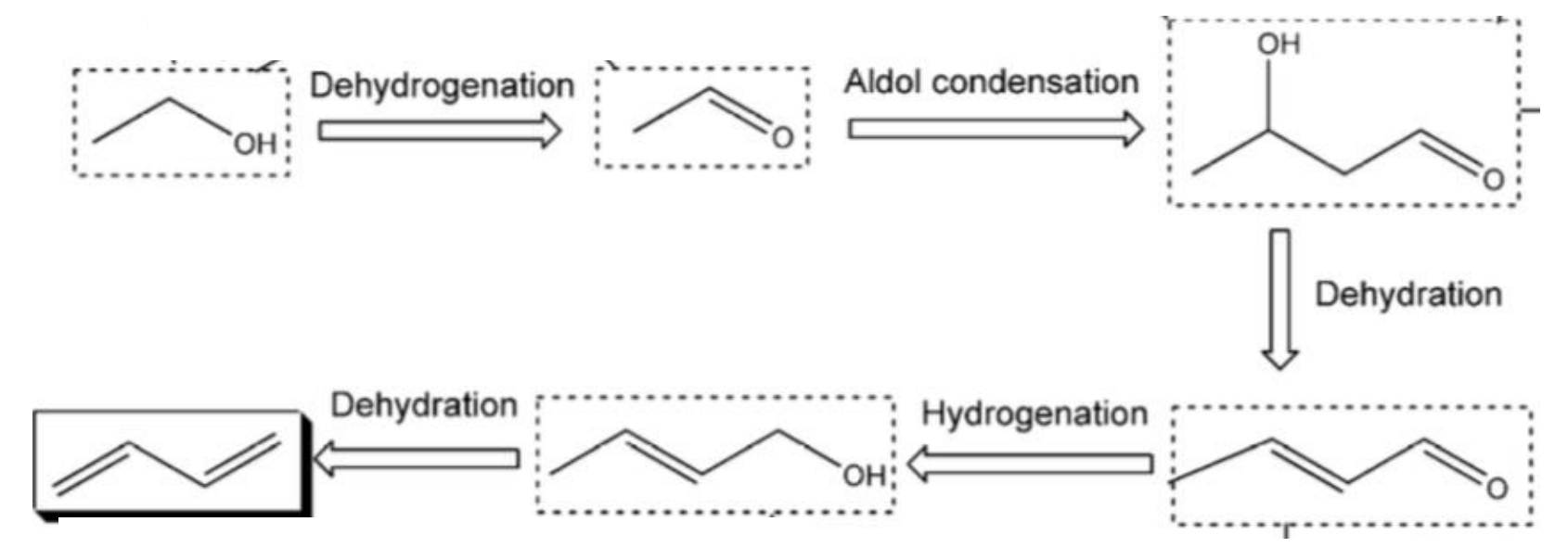

Figure 5: Generalized reaction network for 1,3-butadiene production from Qi et al. One ethanol molecule is dehydrogenated to form acetaldehyde, which then couples with another ethanol to form a four-carbon chain which then undergoes two dehydrations and a hydrogenation to form the final product, 1,3-butadiene [15].

Historic ethanol-to-BD production routes were proven to work in a somewhat limited fashion with up to 60 percent butadiene yield and 70 percent selectivity achieved by the German company I.G. Farben at atmospheric pressures [15]. These methods largely fell out of favor in industry by the 1960s as massive naphtha cracking operations in ethylene plants began to be able to produce cheaper 1,3-butadiene as a side product. Although naphtha cracking involves many side products and separation is an issue, the massive scale of these ethylene plants makes them able to make less expensive butadiene monomer than was possible using ethanol as a primary feedstock [14]. However, due to environmental and public health concerns with naphtha cracking as well as the relative abundance of inexpensive and potentially renewable ethanol in the US, research interest in butadiene production from ethanol is beginning to be renewed [21].

\section{Lebedev Process and Other One-Step Methods}

There are inherent challenges to performing the several intermediate reactions needed to convert ethanol to 1,3-butadiene with a commercially suitable selectivity. In 1910, Russian chemist Sergey Lebedev developed a process to do such, employing the following intermediate steps [16,22]: 
- Hydrogenation of ethyl alcohol to form acetaldehyde

- Condensation of acetaldehyde with another ethanol to form crotonaldehyde

- Reduction of crotonaldehyde to form crotyl alcohol

- Dehydration of crotyl alcohol and rearrangement to form the final product, 1,3-butadiene

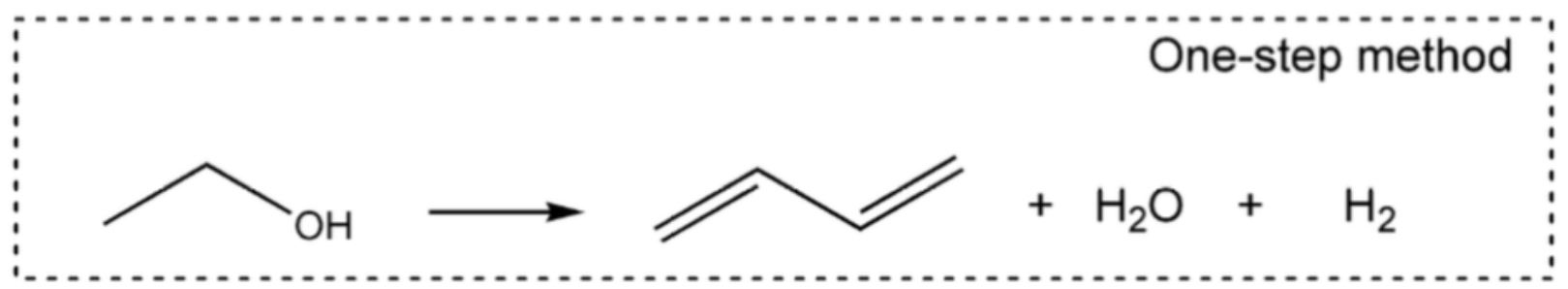

Figure 6: Simplified reaction model for the one-step (Lebedev) production of 1,3-butadiene from ethanol. Two ethanol molecules undergo all intermediate steps to form 1,3-butadiene in one reactor. From Qi et al [15].

Although Lebedev was able to use his process to demonstrate the potential for the creation of synthetic butadiene rubber sourced from ethanol, his results would be considered unacceptable by today's standards, with only 25 percent maximum butadiene selectivity and 10-13 percent yield of desired products [16]. However, many improvements were made to Lebedev's original process as scientists learned more about the reaction mechanism and demand continued to increase for practical, inexpensive synthetic rubber.

One of the key improvements made to the original Lebedev process has been in the more effective catalysis of the complicated main reaction path. Talc, or a magnesia-silicate $\left(\mathrm{MgO} / \mathrm{SiO}_{2}\right)$ crystal, has been shown to be an effective catalytic medium for the ethanol-to-BD synthesis route $[17-19,22]$. The conversion and selectivity for the desired product, 1,3butadiene, has varied somewhat in the literature due to altered experimental conditions and the use of additional elements as promoters. Oxides of chromium, nickel, silver, zinc, and copper as well as metallic silver have been used as promoters for the Lebedev process with wildly varying success [17]. Tret'yakov et al. took likely the closest approach to the original Lebedev process, using $\gamma$-aluminum oxide with 25 percent by weight zinc nitrate catalyst. Despite high initial 
activity, the catalyst showed a sharp decrease in yield over time across multiple different catalyst preparation methods. As a result, none of these $\gamma-\mathrm{Al}_{2} \mathrm{O}_{3}$-based catalysts eclipsed 24 percent yield of the desired product [16]. Angelici et al. had greater success using copper-promoted talc catalysts, achieving a maximum of 40 percent 1,3-butadiene yield. This $\mathrm{Cu}$ promoter was proposed to aid in the selectivity of the first step, acetaldehyde formation, by blocking acidic sites that would form the key undesired products ethylene and diethyl ether [17]. By blocking these "dead-end" byproducts early in the reaction network, that ethanol which is converted is hopefully maximized to form the most butadiene possible. Hayashi et al. also achieved some success using a magnesia-silica based catalyst to form butadiene from ethanol, this time using zinc as a promoter and employing density functional theory (DFT) to model the reaction. At lower ethanol conversion levels, selectivity was dominated by acetaldehyde, confirming its status as a key intermediate. 1,3-butadiene selectivity then steadily rises with conversion, until conversion reaches 60 percent or higher and butene begins to dominate the reactor effluent. Using DFT, zinc was found to aid in the initial step of acetaldehyde formation, but also weakened the basicity of the catalyst and thus hurt production of the subsequent steps of the reaction network [18]. Akiyama et al. employed a germanium-talc catalyst that exhibited remarkably high selectivity for 1,3-butadiene of 71 percent, but with only a 44 percent ethanol conversion rate [22].

Investigation into effective catalysis of the Lebedev process is ongoing. Key characteristics in a successful catalyst would be a high number of basic active sites, which aid in the formation of double bonds via reduction, as well as the ability to discriminate between the relatively weak $\mathrm{C}-\mathrm{C}$ bonds in the final $\mathrm{C}_{4}$ product and the stronger bonds found in the reactants. With so many possible side reactions, this problem is unlikely to have a simple solution. 


\section{Ostromislensky Process and Other Two-Step Methods}

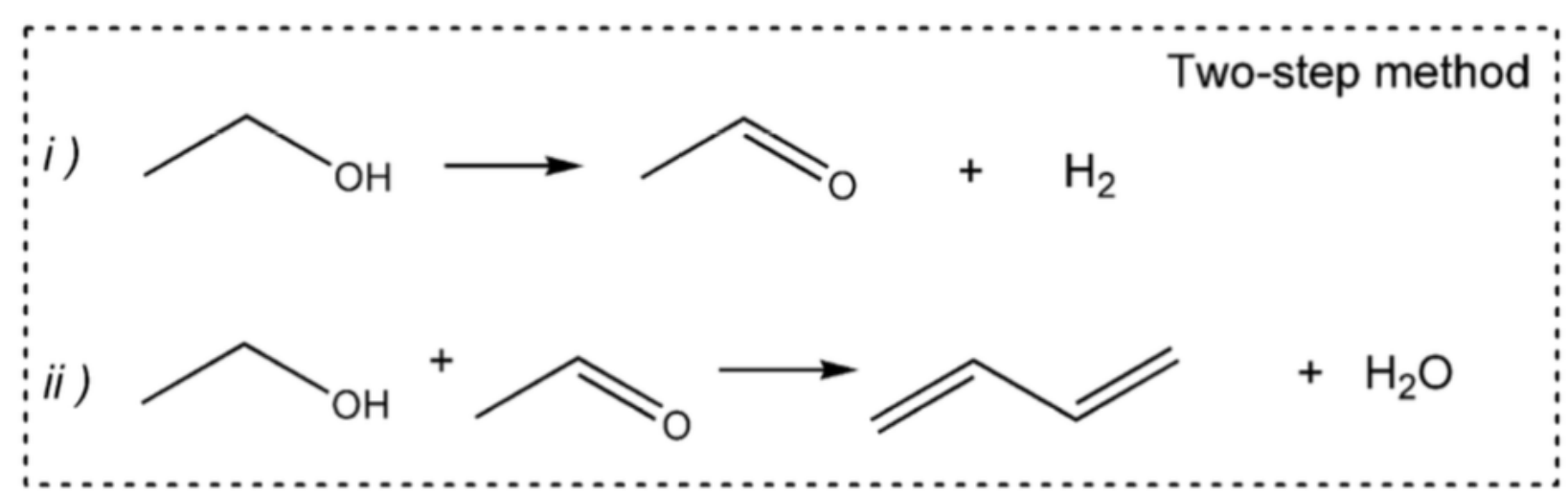

Figure 7: Simplified reaction model for the two-step production of 1,3-butadiene from ethanol. In contrast to the one step method, some ethanol is dehydrogenated to form acetaldehyde in a separate first step before coupling with ethanol in the second step and undergoing the necessary dehydrations to form the final product. From Qi et al [15].

Around the same time that the Lebedev synthesis process was highly popular for rubber production in the World War II-era Soviet Union, the Ostromislensky process was employed by American companies for their war effort [22]. The key difference between the Lebedev and Ostromislensky model was the separation of the highly important initial ethanol-to-acetaldehyde step from the subsequent reactions. Afterwards, a similar aldol condensation to the Lebedev method followed by rearrangements and dehydrations yielded 1,3-butadiene in a separate reactor, with reported yields reaching over 60 percent with very high purity in the final product. In the typical catalytic arrangement, the first step to form acetaldehyde was performed over a copper-doped silica catalyst, similar to the catalyst used in the Lebedev process. The subsequent conversion to butadiene was catalyzed by a tantalum-based metallic catalyst [24]. As in any chemical process, the suppression of side products, particularly ethylene which actually has a lower energy barrier of formation than acetaldehyde in this case, is of critical importance to attaining satisfactory yields [12]. Figure 8 contains a more detailed view of the Ostromislensky process and rearrangement, with key intermediates listed and named. 


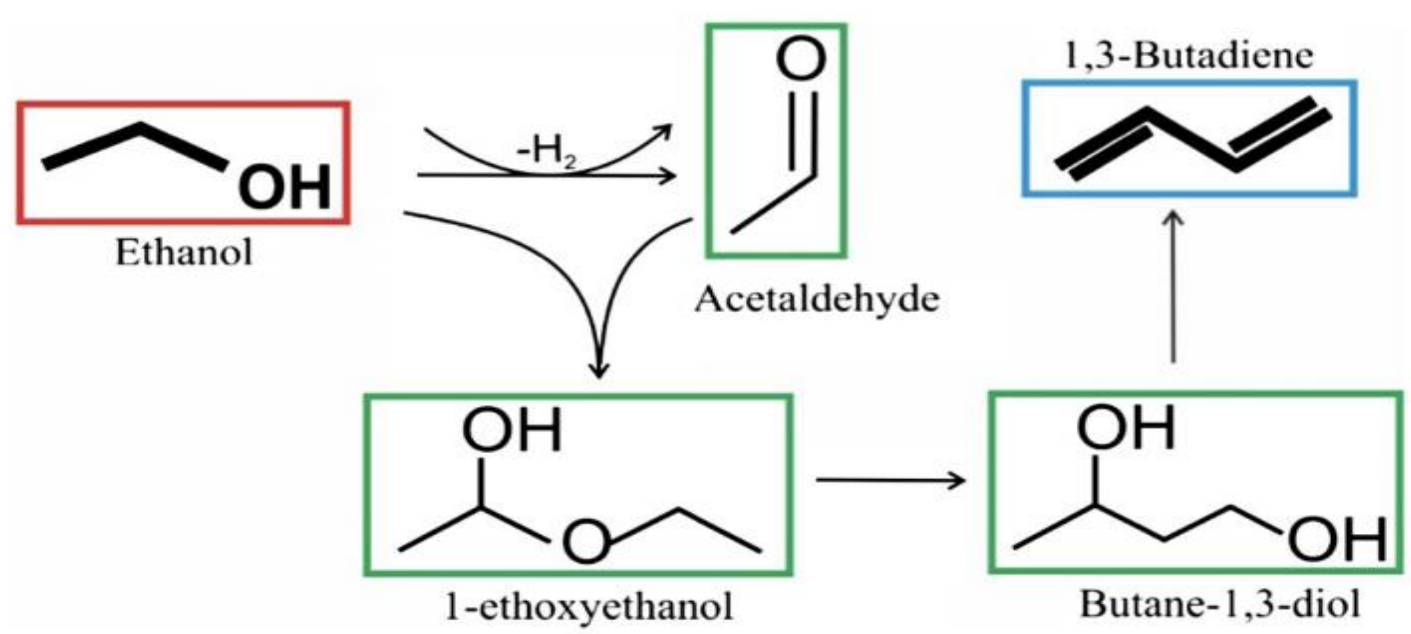

Figure 8: A detailed presentation of the Ostromislensky synthesis main reaction pathway. In an initial step, ethanol is dehydrated to form acetaldehyde, then in a separate reactor the two are combined and rearranged to form butane-1,3-diol. At this point the diol product undergoes two dehydrations to form the diene product.

From Taifan et al. [24]

Although it was not widely commercially implemented as the Lebedev and

Ostromislensky syntheses were, the Fripiat mechanism is a third proposed pathway for butadiene synthesis from ethanol feed. This method also employs two reaction steps, and also utilizes the nearly unavoidable ethylene side product as an intermediate. In the first step, some ethanol is dehydrogenated to form acetaldehyde, while an equal amount of ethanol is dehydrated to form ethylene. In the following stage, in what is called a Prins reaction, the ethylene is combined with the acetaldehyde to form a butenol, i.e. containing both a $\mathrm{C}=\mathrm{C}$ double bond and an alcoholic group. This intermediate undergoes a dehydration to form the desired 1,3-butadiene product [12,24]. This reaction can be catalyzed similarly to other routes, with magnesia-silica having proven to be an effective catalyst for the Prins reaction. The magnesia is theorized to provide basic active sites, where the dehydrogenation and Prins steps are assisted, while the silica offers more acidic sites where dehydration of the butenol intermediate is likely to occur [12]. Figure 9 contains a detailed diagram of the Fripiat process with intermediates listed and named. 


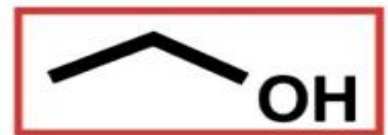

Ethanol

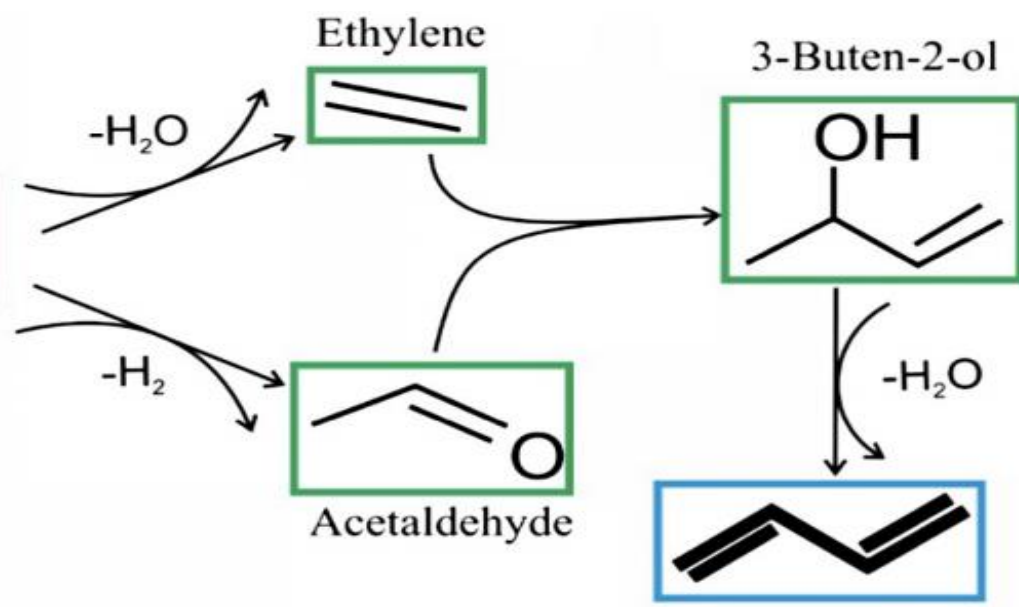

1,3-Butadiene

Figure 9: Detailed presentation of the main Fripiat reaction pathway. In two concurrent first steps, ethanol is dehydrated and dehydrogenated to ethylene and acetaldehyde, respectively. These two species are combined via the Prins reaction, then dehydrated to form the desired final butadiene product. From Taifan et al [24].

There are some reasons that Fripiat's Prins mechanism could be attractive relative to the more-established Lebedev and Ostromislensky routes. As alluded to previously, the energy barrier for ethanol dehydration to ethylene is lower than the barrier for ethanol dehydrogenation to acetaldehyde, as was confirmed via DFT calculations [24]. By utilizing this virtually unavoidable reaction as part of the main pathway, formation of undesired products could potentially be suppressed. This is supported by Fripiat's reported selectivity reaching 80 percent for 1,3-butadiene in some trials [12]. Unfortunately, since Fripiat's original work, relatively little research interest has been devoted to the Prins mechanism for ethanol-to-BD synthesis, although this could change in the coming years with such a large supply of ethanol available.

\section{$\mathrm{C}_{4}$ Olefin Production from $\mathrm{C}_{4}+$ Sources}

From the 1960 s to the present, $\mathrm{C}_{4}$ olefin production, and specifically butadiene production, has been dominated by $\mathrm{C}_{4}+$ feedstocks rather than by synthesizing from lower-order hydrocarbons [3,12-14]. Prices for these olefins tend to fluctuate widely due to their status as a coproduct beholden to the supply and demand patterns of the more commercially important products ethylene and butane [12]. Indeed, historically speaking, very few stand-alone, on- 
purpose butadiene plants have existed in the United States [14]. Naphtha cracking operations at massive ethylene plants along the Gulf Coast produce large amounts of mixed $\mathrm{C}_{4}$ streams that would otherwise become waste. From this mixed butenes stream, some 1,3-butadiene and other useful coproducts can be extracted, although these chemically similar species can be very costly to separate $[12,14]$. After the butadiene is extracted, typically isobutylene is the next product distilled off from the rest of the raffinate, followed by 1-butene, then trans- and cis-2-butenes. These other, lesser-known $\mathrm{C}_{4}$ olefins can be used as gasoline precursors or additives, but outside of that industry they typically have little established commercial significance and are not in high demand.

For other $\mathrm{C}_{4}$ species, particularly butane and butene, the Houdry dehydrogenation process is employed to convert the saturated butane into 1,3-butadiene. Zhang et al. noted that degradation of catalysts was an issue for this process and used carbon nanotubes in an attempt to increase catalyst durability and thus improve efficiency. Stability and conversion of these CNT catalysts, particularly when oxidized in strong acid and doped with phosphorus, was very stable over periods of 100 hours and beyond. However, maximum yield of $\mathrm{C}_{4}$ olefins maxed out at only 13.8 percent, with roughly even amounts of 1-butene, 2-butene, and 1,3-butadiene [13]. Although these processes can be costly and not particularly thermodynamically efficient due to high separation costs, the sheer size of these ethylene plants and the economy of scale have caused these $\mathrm{C}_{4}$ extraction and dehydrogenation side units to dominate $\mathrm{BD}$ production for decades.

\section{Olefin Metathesis}

Another major topic so far not discussed in this review is the field of olefin metathesis. Olefin metathesis refers to the rearrangement of carbon chains by breaking a double bond, 
changing the functional groups contained on either side, and reforming the double bond in the new arrangement. For example, two propene molecules could be metathesized, via the scission of a $\mathrm{C}=\mathrm{C}$ bond in both molecules forming two $\mathrm{C}_{1}$ radicals and two $\mathrm{C}_{2}$ radicals. Via selective dehydrogenation reactions, the like radicals combine together to form ethylene and 2-butene. This process was inadvertently discovered by the Phillips company while attempting to alkylate excess propylene to form high-octane gasoline. Using a supported molybdenum catalyst, however, they found that the olefins tended to split rather than coagulate to form longer chains, leading to the high yield of 2-butene and ethylene [31]. Today, however, due to high propylene demand in the $21^{\text {st }}$ century, the reverse reaction has become significantly more popular; with excess ethylene being dimerized to form the 2-butene reactant, thus allowing for relatively efficient conversion between ethylene and propylene based on demand and market trends $[26,31]$.

Multiple variations now exist on this method since its inception during the 1960s, including the Phillips triolefin process to produce $\mathrm{C}_{2}$ and $\mathrm{C}_{4}$ olefin products from excess $\mathrm{C}_{3}$ olefins, and the Shell Higher Olefin Process (SHOP) to produce larger $\mathrm{C}_{6}$ and/or cyclic olefins [26]. Interestingly, this makes olefin metathesis one of the few major fields in industrial petrochemistry to primarily be developed and employed on an commercial scale in the last 50-60 years [31]. Multiple metal oxide catalysts have been shown to have both high selectivity and high activity for olefin metathesis, with metals like rhenium showing an ability to bind propene at high temperatures, facilitating the addition of an additional carbon from a passing propene molecule [26]. Howell et al. noted an exceptionally high selectivity of $98 \%$ for the two desired products, ethylene and 2-butene, using a tungsten oxide-based catalyst. Investigation of the reaction using chromatography and other methods indicated that very little secondary metathesis 
had occurred in the form of the desired products re-bonding to the metal, showing great promise for tungsten oxide as a selective catalyst to activate propylene alone without disturbing the desired ethylene or butylene molecules [25]. Lwin and Wachs noted that although rhenia-based catalysts are more expensive, leading to less research on their potential usage, activity for olefin metathesis using rhenia is typically quite high, and this effect increases with the size of the reacting olefin [26].

Although olefin metathesis can be used to create $\mathrm{C}_{4}$ olefins, the most commonly produced via established OM methods is 2-butene. 2-butene is a relatively low-value product with applications mostly in gasoline formulation. Little to no literature exists on the production of higher value $\mathrm{C}_{4}$ olefins from 2-butene, which could be for a variety of reasons. Structurally, the dehydrogenation of 2-butene to form butadiene is difficult in comparison to other potential BD precursors, such as 1,4-butanediol, 1-butene, or $n$-butane, for which literature on conversion to dienes do exist [12-14, 27]. Additionally, the lone double bond in 2-butene would need to be broken and reformed in order to form the 1,3-butadiene molecule, whereas this additional step would not be required for the aforementioned molecules which mainly rely on simpler dehydrations and/or dehydrogenations to be converted to BD. Thus, in order for an OM-related scheme to compete with existing $\mathrm{C}_{4}$ olefin production, a more direct route to highly valuable product would be necessary.

\section{Cost/Benefit Analysis for Selected Reaction Schemes}

At this point in the review, several alternative schemes to produce $\mathrm{C}_{4}$ olefins have been identified, each being implemented to some degree in industrial chemistry past or present, or at the very least having a significant amount of research and literature available on the topic. In order to determine which of these schemes are more worthy of continued development than 
others, the following sections represent an attempt to get these varied schemes on "equal footing," that is, try to compare each scheme on the basis of its pros and cons, what kind of energy inputs will be required, prices of raw materials and potential products, and other safety and economic considerations. Schemes that may be compared on this basis include but are not limited to:

- Ethylene cracking byproduct/mixed butene stream (most common method used in industry today)

- Butadiene synthesis from ethanol (multiple routes developed during WWII)

- Reverse reaction Phillips triolefin process (propylene to butadiene)

- Bio-based catalysis (the Genomatica method)

- Natural gas improvement (abundant and inexpensive feedstock)

- Modified Fischer-Tropsch scheme (produce $\mathrm{C}_{2}+$ alcohols)

- Microwave-assisted synthesis (produce $\mathrm{C}_{2}+$ hydrocarbons)

As some of these schemes undoubtedly show more promise for the production of $\mathrm{C}_{4}$ olefins than other methods, Table 1 provides a simplified overview of the inputs required, desired products, major pros and cons, as well as information on current/historic usage of each scheme. Later, the known reaction networks and enthalpies of said reactions, as well as reported product yields from the literature, will be used to establish a rough quantitative comparison of the collected methods for $\mathrm{C}_{4}$ olefin production. 
Table 1: Major information on selected $\mathrm{C}_{4}$ olefin production schemes

\begin{tabular}{|c|c|c|c|c|c|}
\hline Scheme & $\begin{array}{c}\text { Raw } \\
\text { Materials }\end{array}$ & $\begin{array}{c}\text { Main } \\
\text { Products }\end{array}$ & Pros & Cons & $\begin{array}{c}\text { Current } \\
\text { Use? }\end{array}$ \\
\hline $\begin{array}{c}\text { Mixed } \\
\text { butene } \\
\text { distillation }\end{array}$ & $\begin{array}{c}\text { Mixed } \mathrm{C}_{4} \\
\text { stream } \\
\text { (byproduct of } \\
\text { naphtha } \\
\text { cracking) }\end{array}$ & $\begin{array}{l}\text { 1,3-butadiene, } \\
\text { isobutene, 1- } \\
\text { butene, et al. } \\
\text { depending on } \\
\text { degree of } \\
\text { separation }\end{array}$ & $\begin{array}{l}\text { Makes use of } \\
\text { potential } \\
\text { waste, } \\
\text { already used } \\
\text { on massive } \\
\text { scale }\end{array}$ & $\begin{array}{l}\text { High energy } \\
\text { demand to } \\
\text { separate, use of } \\
\text { non-renewables, } \\
\text { health hazards }\end{array}$ & $\begin{array}{l}\text { Comprises } \\
\text { vast majority } \\
\text { of } \mathrm{C}_{4} \text { olefin } \\
\text { production in } \\
\text { N. America }\end{array}$ \\
\hline $\begin{array}{l}\text { Ethanol-to- } \\
\text { Butadiene }\end{array}$ & $\begin{array}{l}\text { Ethanol, } \\
\text { ideally from } \\
\text { renewables } \\
\text { (corn, sugar) }\end{array}$ & 1,3-butadiene & $\begin{array}{l}\text { Highly } \\
\text { researched } \\
\text { field, feed is } \\
\text { abundant and } \\
\text { potentially } \\
\text { renewable }\end{array}$ & $\begin{array}{l}\text { Large reaction } \\
\text { network, many } \\
\text { undesired } \\
\text { products, } \\
\text { relatively low } \\
\text { yields }\end{array}$ & $\begin{array}{l}\text { Popular during } \\
\text { mid- } 20^{\text {th }} \\
\text { century, still } \\
\text { some usage in } \\
\text { Asia }\end{array}$ \\
\hline $\begin{array}{c}\text { Olefin } \\
\text { metathesis }\end{array}$ & Propylene & $\begin{array}{l}\text { Ethylene and } \\
\text { 2-butene }\end{array}$ & $\begin{array}{l}\text { Highly } \\
\text { researched } \\
\text { field, feed is } \\
\text { abundant }\end{array}$ & $\begin{array}{c}\text { Relatively low- } \\
\text { value products, } \\
\text { difficulty } \\
\text { converting/selling } \\
\text { 2-butene }\end{array}$ & $\begin{array}{c}\text { Reverse } \\
\text { reaction is } \\
\text { more common } \\
\text { (high demand } \\
\text { for } \\
\text { polypropylene) }\end{array}$ \\
\hline $\begin{array}{c}\text { Bio-based } \\
\text { catalysis }\end{array}$ & $\begin{array}{l}\text { Bacteria, } \\
\text { food, heat }\end{array}$ & $\begin{array}{c}\text { 1,3-butadiene, } \\
\text { either directly } \\
\text { or via 1,4- } \\
\text { butanediol }\end{array}$ & $\begin{array}{l}\text { Renewable, } \\
\text { reduced } \\
\text { danger to } \\
\text { environment }\end{array}$ & $\begin{array}{c}\text { Proprietary, } \\
\text { limited data } \\
\text { available, } \\
\text { unproven on } \\
\text { commercial scale }\end{array}$ & $\begin{array}{c}\text { At least one } \\
\text { industrial plant } \\
\text { is operational, } \\
\text { more in } \\
\text { development } \\
\end{array}$ \\
\hline $\begin{array}{l}\text { Microwave- } \\
\text { assisted } \\
\text { methane } \\
\text { conversion }\end{array}$ & $\begin{array}{c}\text { Methane } \\
\text { (likely } \\
\text { natural gas) }\end{array}$ & $\begin{array}{l}\text { Higher order } \\
\text { hydrocarbons } \\
\text { (different } \\
\text { results from } \\
\text { other catalysts) }\end{array}$ & $\begin{array}{l}\text { Avoids } \\
\text { combustion } \\
\text { of feed, high } \\
\text { olefin yield } \\
\text { in some } \\
\text { instances }\end{array}$ & $\begin{array}{l}\text { Very complex } \\
\text { reaction network, } \\
\text { limited data } \\
\text { available }\end{array}$ & $\begin{array}{l}\text { Mostly } \\
\text { experimental } \\
\text { use for } \\
\text { hydrocarbon } \\
\text { synthesis }\end{array}$ \\
\hline
\end{tabular}

With the exception of the mixed butene scheme, which relies almost entirely on distillation of the various chemically-similar $\mathrm{C}_{4}$ components derived from naphtha cracking, each scheme listed above relies on some sort of reaction network, which contain some amount of undesired reactions and products, thus introducing selectivity and yield considerations for the remaining schemes. Additionally, the energy requirements for the reaction can be roughly 
compared using enthalpies of reaction, most of which are obtainable through the literature. Of course, these calculations are mostly theoretical and each of the schemes besides the aforementioned mixed butene distillation likely requires additional research and development in order to compete commercially with the massive naphtha cracking operations in the economy of scale. Finally, thermodynamic data such as the heat of mixing for the various desired and side products can be used to roughly estimate the amount of energy that would be needed to distill and separate the main products from the rest of the effluent. Due to a lack of $100 \%$ efficiency, these calculations are likely to underestimate the total energy needed for distillation, but will provide an interesting data point when it comes to comparing the energy demands for these olefin production schemes.

\section{Mixed Butenes Distillation Scheme Analysis}

The mixed butenes distillation scheme is likely the simplest of the assembled methods, as the raw material already contains the desired products, $\mathrm{C}_{4}$ olefins, in significant quantities and thus does not require any additional reaction steps. The raw material, mixed $\mathrm{C}_{4}$ hydrocarbons, is sold by multiple companies as a byproduct from naphtha cracking. At least two successive distillations are performed to remove the most valuable products, which comprises the main operating costs for the scheme [49]. First, butadiene is extracted leaving behind "C4R1," or $\mathrm{C}_{4}$ Raffinate-1. This raffinate itself is listed by some companies, including Dow and Royal Global Energy, as a product. Next, isobutylene is extracted, which has a variety of uses including polyisobutylene (PIB) production, a polymer used for sealing and insulation for plastic products [33]. This extraction leaves behind $\mathrm{C} 4 \mathrm{R} 2$, or $\mathrm{C}_{4}$ Raffinate-2, which is sold as a commodity similarly to C4R1. Additional extraction to obtain 1-butylene and other compounds present in the raffinate can be performed, but this is not as common due to lack of demand and difficulty of 
separation. Other common uses for C4R2 if not further separated are methyl ethyl ketone (MEK) and fuel production. Both of these raffinate products are sold primarily in Europe and have little market fluidity due to lack of demand and the fact that most useful $\mathrm{C}_{4}$ extractions are simply performed on-site by the company which cracked the naphtha to obtain the mixed $\mathrm{C}_{4}$ stream in the first place [33]. For the purposes of this analysis, the sole raw material for this scheme is mixed $\mathrm{C}_{4}$ and the products are 1,3-butadiene, isobutylene, and $\mathrm{C}_{4}$ raffinate- 2 .

Table 2: Important data for mixed butene distillation scheme

\begin{tabular}{|c|c|c|c|}
\hline Species & $\begin{array}{c}\text { Commodity Price } \\
(\$ / \mathrm{kg})\end{array}$ & $\begin{array}{c}\text { Molar Mass } \\
(\mathrm{kg} / \mathrm{mol})^{[35]}\end{array}$ & $\begin{array}{c}\text { Heat of Formation } \\
(\mathrm{kJ} / \mathrm{mol})^{[35]}\end{array}$ \\
\hline $\begin{array}{c}\text { Mixed } \mathrm{C}_{4}{ }^{*} \\
(\text { feed) }\end{array}$ & $\$ 1.00^{[36]}$ & 55.50 & 26.13 \\
\hline $\begin{array}{c}\text { 1,3-butadiene } \\
\text { (product) }\end{array}$ & $\$ 1.00^{[37]}$ & 54.09 & 110.83 \\
\hline $\begin{array}{c}\text { Isobutylene } \\
\text { (product) }\end{array}$ & $\$ 1.00^{[38]}$ & 56.11 & -17.05 \\
\hline $\begin{array}{c}\mathrm{C}_{4} \text { Raffinate-2** } \\
\text { (product) }\end{array}$ & Unknown & 56.69 & -42.43 \\
\hline
\end{tabular}

*-Heat of formation and mass for the mixed $\mathrm{C}_{4}$ determined using standard compositional data (wt. percent): $41 \%$ butadiene, $22 \%$ isobutylene, $15 \%$ 2-butene, $11 \%$ 1-butene, $7 \%$ n-butane, $4 \%$ isobutane [34]

**-Heat of formation and mass for $\mathrm{C}_{4}$ raffinate-2 determined using standard compositional data (wt. percent): 39\% 2-butene, 31\% 1-butene, 18\% n-butane, 11\% isobutane, 1\% butadiene/isobutylene [34]

As mentioned previously, due to a feed that is typically produced on-site as a cracking byproduct and a lack of necessary reactions to produce the desired olefin products, the main cost associated with this method is the massive distillation process needed to separate as many as a dozen different chemical compounds from one another. This problem is exacerbated by the chemical similarity in terms of boiling points and other physical properties of the various $\mathrm{C}_{4}$ hydrocarbon species [49]. The most industrially important $C_{4}$ olefins tend to have very similar prices which fluctuate along with the demand for their respective derivatives. Thus, current market prices may dictate how much separation is employed by companies producing mixed $\mathrm{C}_{4}$ as a byproduct from naphtha cracking. If butadiene and/or isobutylene prices are too low at any 
given time to overcome the high energy costs associated with separation, a plant could opt not to undergo the separations and instead use or sell the mixed raffinate as is. This fluctuation in supply is a likely contributor to the unstable market price of butadiene, among other chemicals.

Due to the inherent complexity of the $\mathrm{C}_{4}$ mixture thermodynamic properties, the exact costs associated with each distillation procedure to remove each individual product are difficult to determine. Empirical data would likely be required to determine the break-even prices for each purified $\mathrm{C}_{4}$ olefin obtainable from the mixed butenes, although accurate process simulations provided by programs such as ChemCAD or Aspen could theoretically accomplish this task. Overall, this scheme dominates industrial production for $\mathrm{C}_{4}$ olefins primarily due to the sheer amount of valuable products that are being formed. However, the amount of energy needed to separate the various components provides the impetus to search for a "greener" and less energyintensive process to produce these valuable commodities.

\section{Ethanol-to-Butadiene Scheme Analysis}

The overall analysis of the ethanol-to-butadiene schemes via the Ostromislensky, Lebedev, or other similar synthesis is slightly more complex due to the reaction network. At least four distinct intermediate reactions are needed to create a four-carbon chain as well as dehydrate the alcoholic groups, leaving behind double-bonded butadiene. Additionally, the complexity of the reaction network practically guarantees the formation of other, less desired products such as ethylene or acetaldehyde. Yield data was determined from Hayashi et al, who were able to achieve about $47 \%$ single-pass ethanol conversion, with $63 \%$ of the product being the valuable chemical butadiene. The most significant side products formed were acetaldehyde ( $10 \%$ of product), diethyl ether ( $8 \%$ of product), and ethylene (6\% of product) [18]. As acetaldehyde is actually an intermediate for the Lebedev mechanism, it can be recycled along 
with unreacted ethanol and thus need not be counted as a "product" the same way that stable ethylene would be. Table 3 contains important basic data for the reactants and major products in the ethanol-to-butadiene Lebedev-based scheme.

Table 3: Important data for ethanol-to-butadiene distillation scheme

\begin{tabular}{|c|c|c|c|}
\hline Species & $\begin{array}{c}\text { Commodity Price } \\
(\$ / \mathrm{kg})\end{array}$ & $\begin{array}{c}\text { Molar Mass } \\
(\mathrm{kg} / \mathrm{mol})^{[35]}\end{array}$ & $\begin{array}{c}\text { Heat of Formation } \\
(\mathrm{kJ} / \mathrm{mol})^{[35]}\end{array}$ \\
\hline $\begin{array}{c}\text { Ethanol } \\
(\text { feed) }\end{array}$ & $\$ 0.20^{[39]}$ & 46.07 & -235.02 \\
\hline $\begin{array}{c}1,3 \text {-butadiene } \\
\text { (product) }\end{array}$ & $\$ 1.00^{[37]}$ & 54.09 & 110.83 \\
\hline $\begin{array}{c}\text { Ethylene } \\
\text { (side product) }\end{array}$ & $\$ 2.10^{[40]^{*}}$ & 28.05 & 52.36 \\
\hline $\begin{array}{c}\text { Diethyl ether } \\
\text { (side product) }\end{array}$ & $\$ 2.00^{[41]^{*}}$ & 74.12 & -252.70 \\
\hline
\end{tabular}

*-Prices for ethylene and diethyl ether from relatively mid-level quantities, likely lower in bulk

Using the heats of formation to roughly estimate energy demand, at least 480 kilojoules would be required to produce one mole of 1,3-butadiene from two moles of ethanol, assuming perfect conversion. However, this vastly underestimates the amount of energy required due to the relatively low yields achieved under even the most ideal conditions. Using Hayashi's yield of $63 \%$ as an adjusting factor, it is likely closer to $750-800$ kilojoules of energy required to produce just one mole of butadiene. Feed costs will also be considerably higher than the low price of ethanol suggests; in addition to the $63 \%$ butadiene yield and $10 \%$ acetaldehyde yield which is recyclable, some $27 \%$ of the effluent is dead-end byproducts, requiring the purchase of additional feed to circumvent this lost product [18].

As with the mixed butenes distillation, these minor products complicate the extraction of the useful butadiene from the rest of the reactor effluent. There are over a dozen species present in quantities of a part per thousand or greater. This complexity makes calculation of energy requirements to purify the butadiene and other valuable products more difficult. As this scheme 
is not in wide industrial use, very little data exists about the operating costs associated butadiene production from ethanol. Advanced simulations such as ChemCAD could theoretically determine these energy demands, although empirical data from current or historical plants would be more accurate.

\section{Olefin Metathesis Scheme Analysis}

Olefin metathesis offers a relatively simple analysis due to the lack of multiple reaction steps, extremely high yields, and therefore, lack of undesired product formation. Historically, companies such as Phillips who patented the triolefin process have employed the reaction in both directions, depending on market trends in demand and price of ethylene and propylene [26]. Both ethylene and propylene are used extensively to create plastics in the form of polyethylene and polypropylene. 2-butene, however, is often sold as a mixture of cis- and trans-2-butene due to the two components having very similar chemical behaviors, thus making effective separation of the two challenging. In fact, many companies that employ the triolefin metathesis process opt to produce their butene feed on site by dimerizing excess ethylene [31]. As a result, fewer commercial processes which employ 2-butene as a feed or intermediate exist than for the highdemand $\mathrm{C}_{2}$ and $\mathrm{C}_{3}$ olefins. Additionally, this caused bulk quantities of 2-butene for sale to be difficult to find. Table 4 contains relevant data to the tri-olefin metathesis scheme.

Table 4: Important data for olefin metathesis scheme

\begin{tabular}{|c|c|c|c|}
\hline Species & $\begin{array}{c}\text { Commodity Price } \\
(\$ / \mathrm{kg})\end{array}$ & $\begin{array}{c}\text { Molar Mass } \\
(\mathrm{kg} / \mathrm{mol})^{[35]}\end{array}$ & $\begin{array}{c}\text { Heat of Formation } \\
(\mathrm{kJ} / \mathrm{mol})^{[35]}\end{array}$ \\
\hline $\begin{array}{c}\text { Propylene } \\
(\text { feed })\end{array}$ & $\$ 1.90^{[42]}$ & 42.08 & 19.93 \\
\hline $\begin{array}{c}\text { Ethylene } \\
\text { (intermediate) }\end{array}$ & $\$ 2.10^{[40]}$ & 28.05 & 52.36 \\
\hline $\begin{array}{c}\text { 2-butene } \\
\text { (product) }\end{array}$ & $\$ 2.00^{*[43]}$ & 56.11 & -9.13 \\
\hline
\end{tabular}

*Large quantity prices for 2-butene could not be located, so the dollar value of 2-butene is almost certain to be less when sold in bulk. 
Although the products ethylene and 2-butene are each currently slightly more valuable per kilogram than the propylene feed, multiple factors point to olefin metathesis being an inefficient way to product $\mathrm{C}_{4}$ olefins. First, the lack of uses for 2-butene leads to bulk sales of the product being difficult or impossible to find, and price shown is based on a relatively small quantity of butene, just 10 kilograms. When selling 2-butene at a commercial scale, i.e. in terms of metric tons, it is reasonable to expect that there may be as much as a twofold or more drop in price per kilogram of 2-butene, based on how similar commodities are sold in bulk.

Additionally, the forward reaction to produce ethylene and 2-butene is actually very slightly endothermic, with roughly over 3 kilojoules per mole of heat required to complete the reaction. This energy requirement, combined with the low (and fluctuating) profit margin achieved by consuming propylene, suggests that current market trends would need to change in order to make $\mathrm{C}_{4}$ olefin production from propylene consistently profitable.

\section{Biocatalysis Scheme Analysis}

After nearly five years of identifying and evaluating potential reaction networks and metabolic processes for bacterial strains, the biochemistry company Genomatica patented a scheme to produce 1,4-butanediol endogenously in Escherichia coli bacteria [7]. Later, direct production of 1,3-butadiene using a similar scheme was patented, with both technologies reaching industrial implementation within the past several years [29]. Both schemes take advantage of the naturally-occurring TCA/citric acid cycle to metabolize simple sugars into important intermediates, then perform a series of non-naturally occurring reactions using foreign enzymes to reach the desired product. These schemes are relatively complex in comparison to others discussed in this review and require many intermediate reactions to reach completion. Table 5 contains relevant data on the chemical species associated with the bio-catalysis methods. 
Table 5: Important data for biocatalysis schemes

\begin{tabular}{|c|c|c|c|}
\hline Species & $\begin{array}{c}\text { Commodity Price } \\
(\$ / \mathrm{kg})\end{array}$ & $\begin{array}{c}\text { Molar Mass } \\
(\mathrm{kg} / \mathrm{mol})^{[35]}\end{array}$ & $\begin{array}{c}\text { Heat of Formation } \\
(\mathrm{kJ} / \mathrm{mol})^{[35]}\end{array}$ \\
\hline $\begin{array}{c}\text { Glucose } \\
\text { (feed) }\end{array}$ & $\$ 0.33^{[44]}$ & 180.16 & -1274 \\
\hline $\begin{array}{c}\text { 1,3-butadiene } \\
\text { (product) }\end{array}$ & $\$ 1.00^{[37]}$ & 54.09 & 110.83 \\
\hline $\begin{array}{c}\text { 1,4-butanediol } \\
\text { (product) }\end{array}$ & $\$ 1.10^{[45]}$ & 90.12 & -426.00 \\
\hline
\end{tabular}

Although the products butadiene and butanediol are much more valuable than the glucose feed, it should be noted that this unnatural metabolism is endothermic; thus, there is a high energy demand for these processes. Due to the extremely low heat of formation of glucose, nearly 1400 kilojoules of heat would be theoretically required to produce a single mole of butadiene under the Genomatica scheme. This high energy requirement for butadiene is mitigated somewhat when 1,4-butanediol is the desired product, with the lower heat of formation resulting in a theoretical energy savings of over 500 kilojoules per mole over the butadiene scheme, without sacrificing any production value due to the diol product's high value in its own right. As of 2017, one bio-butanediol plant was in operation in Italy by the company Novamont which had licensed Genomatica's Bio-BDO technology. In less than a year of operation, the plant had operated as promised, produced over 10,000 tons of product and was consistently producing at scale according to company press releases, although more specific economic data was not available [50].

\section{Microwave-Assisted Methane Conversion Scheme Analysis}

Methane conversion using microwaves to overcome energy barriers is another relatively new and under-researched field. Two main reactions are employed: first, methane is dimerized to form ethylene and hydrogen gas. Next, the ethylene is in turn dimerized to form 1-butene. Microwave heating is interesting as it appears to offer a way to impart high energy to reactive 
systems such as flammable methane and ethylene gas causing them to react, without combusting the raw materials. Additionally, methane is a highly abundant and relatively inexpensive raw material, further generating interest in its potential as a hydrocarbon building block. Table 6 contains relevant information for the reactants and products of the microwave-assisted heating scheme.

Table 6: Important data for microwave-assisted methane conversion scheme

\begin{tabular}{|c|c|c|c|}
\hline Species & $\begin{array}{c}\text { Commodity Price } \\
(\$ / \mathrm{kg})\end{array}$ & $\begin{array}{c}\text { Molar Mass } \\
(\mathrm{kg} / \mathrm{mol})^{[35]}\end{array}$ & $\begin{array}{c}\text { Heat of Formation } \\
(\mathrm{kJ} / \mathrm{mol})^{[35]}\end{array}$ \\
\hline $\begin{array}{c}\text { Methane } \\
(\text { feed })\end{array}$ & $\$ 0.19^{*[46]}$ & 16.04 & -74.53 \\
\hline $\begin{array}{c}\text { Ethylene } \\
\text { (intermediate) }\end{array}$ & $\$ 2.10^{[40]}$ & 28.05 & 52.36 \\
\hline $\begin{array}{c}\text { 1-butene } \\
\text { (product) }\end{array}$ & $\$ 1.00^{[47]}$ & 56.11 & 0.05 \\
\hline $\begin{array}{c}\text { Acetylene } \\
\text { (side product) }\end{array}$ & $\$ 0.16^{* *[48]}$ & 26.04 & 228.26 \\
\hline
\end{tabular}

*Methane priced only by volume so ideal gas law was used to convert to mass/moles, using 200 bar product specifications and standard temperature of $290 \mathrm{~K}$.

**-Assuming standard max tank capacity of $6.5 \mathrm{~kg}$ acetylene used by other vendors

Both dimerizations are extremely endothermic in nature, hence the use of high-energy

microwave radiation in order to provide sufficient energy for the reaction to occur. The formation of ethylene from methane requires over 200 kilojoules per mole of ethylene, and the formation of 1-butylene from ethylene requires over 100 kilojoules per mole. This high energy demand is offset by the high values of butene and ethylene relative to methane. Care was taken to avoid an additional dehydrogenation of the ethylene intermediate to form acetylene by pumping excess hydrogen gas into the reactor, which resulted in very low yields of that relatively inexpensive byproduct. Experimental data is mostly limited to the work done by Lu et al., who reported relatively high selectivities of roughly $90 \%$ 1-butene from the second dimerization reaction using a molybdenum-doped zeolite catalyst [1]. More studies should attempt to recreate 
these promising results, which could provide another alternate pathway to efficiently producing $\mathrm{C}_{4}$ olefins.

\section{Discussion}

Considering the mixed butenes distillation scheme which dominates current $\mathrm{C}_{4}$ olefin production as the "control" method, there is some potential for improved outcomes using the various alternative schemes described herein. In particular, the bio-based catalysis scheme stood out as one of the more promising methods, due to a relatively simple setup with high yields and few waste products, an inexpensive and renewable feed, and potential for high profit margin. Similarly, the direct production of butenes from methane using microwave radiation could take advantage of an abundant feed in methane to produce high value products with little waste, although more research is needed into the microwave method in order to replicate the successful study by Lu et al. which produced 1-butene from methane with relatively high selectivity.

Thermodynamically speaking, all of the synthetic routes to major $\mathrm{C}_{4}$ olefins are endothermic and will require large energy inputs. With just a few hundred theoretical kilojoules per mole, the microwave radiation reaction scheme has the lowest energy barriers, followed by the ethanol-to-butadiene scheme (adjusted for yield). The biocatalysis scheme requires the greatest theoretical energy input, but this cost is offset by the renewability of the feed and the lack of wastes. The ethanol-to-BD scheme, although it is by far the best understood synthetic pathway to produce $\mathrm{C}_{4}$ olefins, suffers from low yields, difficult separation of byproducts/waste, as well as stagnation after being studied for nearly a century. Olefin metathesis is also a highlyresearched field and boasts the highest proven yields ( $99 \%)$ of any of the processes discussed herein, but the usefulness and industrial demand for the product 2-butene is low in relation to other $\mathrm{C}_{4}$ olefins like butadiene or isobutylene, leading to the reverse reaction forming propylene 
being more profitable. Comparing the schemes based on their post-reactor separation costs was a challenge, but the high yields from biocatalysis, followed by methane microwave radiation, suggest that their product purification costs would be relatively minimal compared to the much more complex ethanol-to-BD scheme or the mixed butene distillation.

\section{Conclusion}

This review as it stands is not an exhaustive survey of olefin production methods. There are gaps that exist, particularly in the connections between the lower order $\mathrm{C}_{1}$ to $\mathrm{C}_{2}$ reactions and the higher order olefin productions. A vast amount of research exists for olefin production from $\mathrm{C}_{4}$ hydrocarbons, as well as $\mathrm{C}_{2}+$ alcohols such as ethanol, but very few studies have attempted to produce $\mathrm{C}_{4}$ olefins from much lower feedstocks than ethanol. Some potential exists for connections between natural gas and these olefins, particularly the microwave-assisted radiation scheme which produced 1-butene from methane via successive dimerizations with relatively high selectivity. This scheme, along with green methods such as Genomatica's selective biocatalysis, show the greatest promise for a sustainable future of $\mathrm{C}_{4}$ olefins which can replace the outdated and inefficient methods which dominate industry today. 


\section{References}

[1] Lu Y.H, Li K, and Lu Y.W. (2017). Microwave-assisted direct synthesis of butene from high-selectivity methane. Royal Society Open Science 4, pp. 171367.

[2] B. Yang, R. Burch, C. Hardacre, P. Hu, and P. Hughes (2014). Mechanistic study of 1,3butadiene formation in acetylene hydrogenation over the Pd-based catalysts using density functional calculations. Journal of Physical Chemistry C 118, pp. 1560-1567.

[3] E.V. Makshina, M. Dusselier, W. Janssens, J. Degreve, P.A. Jacobs, and B.F Sels (2014). Review of old chemistry and new catalytic advances in the on-purpose synthesis of butadiene. Chemical Society Review 43, pp. 7917.

[4] I.T. Trotus, T. Zimmermann, N. Duyckaerts, J. Geboers, and F. Schueth (2013). Butadiene from acetylene ethylene cross metathesis. Royal Society of Chemistry.

[5] X.J. Cai and Y.H. Hu (2019). Advances in catalytic conversion of methane and carbon dioxide to highly valuable products. Energy Science and Engineering 7, pp. 4-29.

[6] M.C. Alvarez-Galvan, N. Mota, M. Ojeda, S. Rojas, R.M. Navarro, and J.L.G. Fierro (2011). Direct methane conversion routes to chemicals and fuels. Catalysis Today 171, pp. 15-23.

[7] N.R. Barton, A.P. Burgard, M.J. Burk, J.S. Crater, R.E. Osterhout, P. Pharkya, B.A. Steer, J. Sun, J.D. Trawick, S.J. Van Dien, T.H. Yang, and H. Yim (2015). An integrated biotechnology platform for developing sustainable chemical processes. Journal of Industrial Microbiology and Biotechnology 42, pp. 349-360.

[8] Y. Liu, K. Murata, M. Inaba, I. Takahara, \& K. Okabe (2013). Mixed alcohols synthesis from syngas over $\mathrm{Cs}$ and $\mathrm{Ni}$ modified $\mathrm{Cu} / \mathrm{CeO} 2$ catalysts. Fuel 104, pp. 62-69.

[9] M. Xiang, D. Li, H. Xiao, J. Zhang, H. Qi, W. Li, B. Zhong, Y. Sun (2008). Synthesis of higher alcohols from syngas over Fischer-Tropsch elements modified $\mathrm{K} / \beta-\mathrm{Mo}_{2} \mathrm{C}$ catalysts. Fuel 87, pp. 599-603.

[10] V.R. Surisetty, A.K Dalai, J. Kozinski (2010). Synthesis of higher alcohols from synthesis gas over Co-promoted alkali-modified $\mathrm{MoS}_{2}$ catalysts supported on MWCNTs. Applied Catalysis A: General 385, pp. 153-162.

[11] L.D. Conde, C. Martin, S.L. Suib (2003). Oligomerization of methane via microwave heating using Raney nickel catalyst. Journal of Catalysis 2018, pp. 201-208.

[12] M.D. Jones (2014). Catalytic transformation of ethanol into 1,3-butadiene. Chemistry Central Journal 8, pp. 53.

[13] J. Zhang, X. Liu, R. Blume, A. Zhang, R. Schloegl, D.S. Su (2008). Surface-modified carbon nanotubes catalyze oxidative dehydrogenation of n-butane. Science 322 (5898), pp. 73-77. 
[14] N.L. Morrow, (1990). The industrial production and use of 1,3-butadiene. Environmental Health Perspectives 86, pp. 7-8.

[15] Y.L Qi, Z.Z. Liu, S.J. Liu, L. Cui, Q.Q. Dai, J.Y. He, W. Dong, and C.X. Bai (2019). The synthesis of 1,3-butadiene and its 2-substituted monomers for synthetic rubbers. Catalysis 9, pp. 97.

[16] V.F. Tret'yakov, R.M. Talyshinskii, A.M. Ilolov, A.L. Maksimov, and S.N. Khadziev (2013). Initiated conversion of ethanol to divinyl by the Lebedev reaction. Petroleum Chemistry, 54 (3) pp. 195-206.

[17] C. Angelici, F. Meirer, M.J. van der Eerden, H.L. Schaink, A. Goryachev, J.P. Hofmann, E.J.M. Hensen, B.M. Weckhuysen, and P.C.A. Bruijnincx (2015). Ex situ and operando studies on the role of copper in $\mathrm{Cu}$-promoted $\mathrm{SiO}_{2}-\mathrm{MgO}$ catalysts for the Lebedev ethanol-to-butadiene process. ACS Catalysis, 5 (10) pp. 6005-6015.

[18] Y. Hayashi, S. Akiyama, A. Miyaji, Y. Sekiguchi, Y. Sakamoto, A. Shiga, T.R. Koyama, K. Motokura, and T. Baba (2016). Experimental and computational studies of the roles of $\mathrm{MgO}$ and $\mathrm{Zn}$ in talc for the selective formation of 1,3-butadiene in the conversion of ethanol. Physical Chemistry Chemical Physics, 18 pp. 25191.

[19] S. Shylesh, A.A. Gokhale, C.D. Scown, D. Kim, C.R. Ho, and A.T. Bell (2016). From sugars to wheels: The conversion of ethanol to 1,3-butadiene over metal-promoted magnesia-silicate catalysts. ChemSusChem, 9 pp. 1462-1472.

[20] V.L. Sushkevich and I.I. Ivanova (2016). Ag-promoted ZrBEA zeolites obtained by postsynthetic modification for conversion of ethanol to butadiene. ChemSusChem 9, pp. 2216-2225.

[21] X.Q. Dong, J. Lu, Y.Z. Yu, and M.H. Zhang (2018). A DFT study on Zr-SBA-15 catalyzed conversion of ethanol to 1,3-butadiene. Physical Chemistry Chemical Physics 20, pp. 12970-12978.

[22] S. Akiyama, A. Miyaji, Y. Hayashi, M. Hiza, Y. Sekiguchi, T.R. Koyama, A. Shiga, and T. Baba (2018). Selective conversion of ethanol to 1,3-butadiene using germanium talc as catalyst. Journal of Catalysis 359, pp. 184-197.

[23] Z. Buniazet, J. Couble, D. Bianchi, M. Rivallan, A. Cabiac, S. Maury, and S. Loridant (2017). Unravelling water effects on solid acid catalysts: Case study of $\mathrm{TiO}_{2} / \mathrm{SiO}_{2}$ as a catalysts for the dehydration of isobutanol. Journal of Catalysis 348, pp. 125-134.

[24] W.E. Taifan, T. Bucko, and J. Baltrusaitis (2017). Catalytic conversion of ethanol to 1,3butadiene on MgO: A comprehensive mechanism elucidation using DFT calculations. Journal of Catalysis 346, pp. 78-91.

[25] J.G. Howell, Y.P. Li, and A.T. Bell (2016). Propene metathesis over supported tungsten oxide catalysts: A study of active site formation. ACS Catalysis 6, pp. 7728-7738. 
[26] S. Lwin and I.E. Wachs (2016). Reaction mechanism and kinetics of olefin metathesis by supported $\mathrm{ReO}_{\mathrm{x}} / \mathrm{Al}_{2} \mathrm{O}_{3}$ Catalysts. ACS Catalysis 6, pp. 272-278.

[27] M. Stalpaert, F.G. Cirujano, and D.E. de Vos (2017). Tetrabutylphosphonium bromide catalyzed dehydration of diols to dienes and its application in the biobased production of butadiene. ACS Catalysis 7, pp. 5802-5809.

[28] S. Sato, R. Takahashi, T. Sodesawa, and N. Yamamoto (2004). Dehydration of 1,4butanediol into 3-buten-1-ol catalyzed by ceria. Catalysis Communications 5, pp. 397400.

[29] M.J. Burk, A.P. Burgard, J. Sun, R.E. Osterhout, and P. Pharkya (2013). Microorganisms and methods for the biosynthesis of butadiene. U.S. Patent 8,580,543 B2.

[30] M.J. Burk, A.P. Burgard, R.E. Osterhout, and J. Sun (2012). Microorganisms for the production of 1,4-butanediol. U.S. Patent 8,178,327 B2.

[31] J.C. Mol (2004). Industrial applications of olefin metathesis. Journal of Molecular Catalysis A: Chemical 213, pp. 39-45.

[32] I. Julian, H. Ramirez, J.L. Hueso, R. Mallada, and J. Santamaria (2019). Non-oxidative methane conversion in microwave-assisted structured reactors. Chemical Engineering Journal 377, 119764.

[33] Independent Commodity Intelligence Services (ICIS). Raffinate-1 and raffinate-2. hs3-euwest-1.amazonaws.com/cjp-rbi-icis-compliance/wp-content/uploads/2013/08/Raffinate1-and-Raffinate-2-Methodology.pdf

[34] T. Streich, H. Koempel, J. Geng, and M. Renger (2016). Secure the best benefit from $\mathrm{C}_{4}$ hydrocarbon processing_Part 2: Economic evaluation. Hydrocarbon Processing 2016, pp. 61-65.

[35] B. Ruscic and D. H. Bross (2019). Active Thermochemical Tables (ATcT) values based on ver. $1.122 \mathrm{~g}$ of the Thermochemical Network; available at ATcT.anl.gov.

[36] Wuhan Monad Medicine Tech Company, Ltd. (2020) Pricing for $\mathrm{C}_{4}$ ethylene manufacturing byproduct. whmonad.lookchem.com/products/CasNo-68476-52-8-High-PurityHydrocarbons-C4-ethylene-manuf-by-product-Cas-No-68476-52-8-24019025.html

[37] Guidechem (2020). Pricing for 1,3-butadiene. guidechem.com/trade/pdetail2250722.html

[38] Simagchem Corporation (2020). Pricing for isobutene. alibaba.com/product-detail/Hot-saleCAS-115-11-7 565253787.html

[39] Shandong Baovi Energy Company, Ltd. (2020). Pricing for ethanol. alibaba.com/productdetail/Top-quality-99-Ethanol-Alcohol-CAS_60724238645.html 
[40] Chengdu Taiyu Industrial Gases Company, Ltd. (2020). Pricing for ethylene. alibaba.com/product-detail/Pure-99-95-industrial-Liquid-Ethylene_60701100938.html

[41] Xilong Scientific Company, Ltd. (2020). Pricing for diethyl ether. zilongchemical.en.madein-china.com/product/KMumkqeHkdpF/China-Analytical-Reagent-Diethyl-Ether-60-297-for-Research-Lab.html

[42] Air Gas Electronic Materials Company, Ltd. (2020). Pricing for propylene. alibaba.com/product-detail/R1270-Propylene-C3H6Gas_62455272095.html?spm=a2700.details.maylikeexp.10.45d72547fye2xk

[43] Chengdu Taiyu Industrial Gases Company, Ltd. (2020). Pricing for 2-butene. alibaba.com/product-detail/99-purity-cis-2-butenegas_60677048068.html?spm=a2700.details.deiletai6.6.65354847Ra07Kf

[44] Luzhou Bio-Chem Technology Company, Ltd. (2020) Pricing for glucose. alibaba.com/product-detail/industrial-liquid-glucose_60442686633.html

[45] Jiangsu Xiangcang Hongrun Trade Company, Ltd. (2020) Pricing for 1,4-butanediol. detail.en.china.cn/provide/p132710507.html

[46] Davido Technology Company, Ltd. (2020) Pricing for methane. alibaba.com/productdetail/Best-quality-and-lower-price-methane_60790510542.html

[47] Chengdu Taiyu Industrial Gases Company, Ltd. (2020). Pricing for 1-butene. https://www.alibaba.com/product-detail/99-5-Industrial-Grade-C4H81_60676465638.html

[48] Shanghai Eternal Faith Industry Company, Ltd. (2020) Pricing for acetylene. alibaba.com/product-detail/99-99-C2H2-Gas-AcetyleneGas_1934501520.html?spm=a2700.details.deiletai6.2.2a9edff1rAxbVJ

[49] M. Gehre, Z.Y. Guo, G. Rothenberg, and S. Tanase (2017). Sustainable separations of C4hydrocarbons by using microporous materials. ChemSusChem 10, pp. 2947-3963.

[50] Genomatica. Novamont plant delivers on performance guarantees (2017). Globe News Wire. globenewswire.com/news-release/2017/06/28/1030003/0/en/Genomatica-delivers-onplant-performance-guarantees.html 